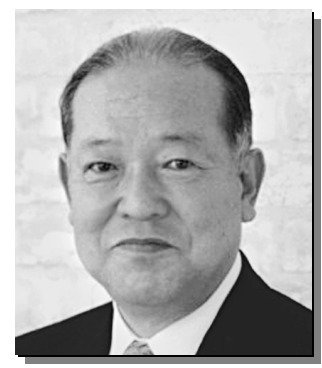

牛尾誠夫君は，昭和 39 年 3 月大阪大学工学部電子工学科を卒業後，昭和 39 年 4 月 三洋電機(株)中央研究所に採用され，昭和 41 年 7 月同退社後，昭和 42 年 4 月大阪大学 大学院工学研究科電子工学専攻修士課程に入学, 昭和 44 年 3 月同修士課程を修了, 昭和 45 年 6 月大阪大学大学院工学研究科溶接工学専攻博士課程を退学後, 同年 7 月 大阪大学工学部附属超高温理工学研究施設助手に採用され, 昭和 50 年 9 月工学博士 (大阪大学) の学位を授与された。昭和 49 年 12 月大阪大学溶接工学研究所助手に配置 換，昭和51年10月同助教授に昇任，平成 2 年 9 月同教授に昇任となり，溶接機器部 門を担当した。平成 8 年 5 月同研究所の改組拡充に伴い，大阪大学接合科学研究所 教授に配置換となり，加工システム研究部門エネルギー制御学分野を担当した。ま た，平成12年 4 月から平成16年 3 月まで同研究所長の要職も務めた。平成 16 年 3 月 に同研究所を退官後，同研究所特任教授として後進の指導にあたり，平成17年 3 月に同研究所を退職した。 平成 17 年 4 月財団法人近畿高エネルギー加工技術研究所長に就任するとともに，平成 18 年 4 月から学校法人 鉄鋼学園産業技術短期大学長の要職を務めている。

同君は民間企業における経験に基づき常に工業的応用を視野に入れつつも，現象の根底をなす素過程ある いは支配要因について深い学理的洞察を加えるというプラズマ科学の分野で培った研究手法を一貫し, アー ク溶接プロセスにおけるプラズマ現象，熱輸送現象，さらには自動制御をはじめとする広範な分野において 多大なる成果を上げた。その一つは，ガスタングステンアーク溶接における熱輸送現象を取り扱ったもので, アーク溶接下における材料は，それ自身がアークの電極として機能しつつ，熱・物質の授受を行うとの観点 に立脚している．すなわち，ガスタングステンアーク溶接におけるタングステン合金除極は，アーク電流を 賄うに十分な熱電子を放出し，かつ高温プラズマからの激しい熱流に曝されるものと捉え，低仕事関数かつ 高沸点の La，Y，Ce などの酸化物を添加した電極材料を開発し，その作動条件・性能について一連の詳しい 解析的研究を行った．開発された新電極材料は，従来のトリア $\left(\mathrm{ThO}_{2}\right)$ 添加タングステン合金と比べて，ア ーク特性ならびに耐久性が優れ，かつトリアのような放射性物質を含まないため，環境的にも好ましい。こ の研究は，タングステン合金放電電極の挙動に関する新しい知見を多く含み，大電流プラズマアークの応用 研究に多大の刺激を与えた。

また，溶接アークを電磁熱流体として取扱う数值解析モデルを世界に先駆けて構築し，ガスタングステン アーク溶接の解析に適用している。アークプラズマの温度や密度, プラズマ気流の流速, アーク圧力など当 時よく理解されていないアークプラズマの状態を定量的に明らかにするとともに，その支配因子を極めて明 解に説明した。さらに，ガスメタルアーク溶接の自動制御の中心的技術であるアークセンサーについても， アーク電流の時間変動と溶接ワイヤの動的溶融現象とを関係づける数值解析モデルを提案し，アークセンサ 一の動特性の解析手段として，アークセンサーシステムの最適動作条件を見出す手法に適用し得ることを示 した.

さらに，我が国で最も汎用の溶接法である炭酸ガスアーク溶接において，アーク電流に矩形パルスを重畳 した際の溶滴移行現象を詳細に観察・解析し, ピーク電流時の電磁ピンチ力による溶滴離脱と, ベース電流 時の低アーク力を適切に組合せることによって，1パルス 1 ドロップの安定した溶滴移行が実現されること を見出した。この成果は，本法の最大の欠点であるスパッ夕発生を著しく低減するもので，ここで得られた 多くの知見は，すでに電流波形制御電源等の炭酸ガスパルスアーク溶接電源の実用化へと結実されている.

このように, 牛尾誠夫君は, その深い学識と卓抜した発想に基づく緻密な研究によって, アーク溶接プロ セスにおけるプラズマ現象, 熱輸送現象, さらには自動制御をはじめとする広範な分野において多大なる成 果を上げ, またこれらの成果を通じて溶接工学に関する知識の普及，さらには技術的革新に大きく貢献して いる。これらにより, 溶接学会論文賞, 溶接学会業績賞, 溶接学会溶接学術振興賞, 溶接学会国際協力賞の 他，村上記念会村上奨励賞，日本鉄鋼協会西山記念賞，英国溶接研究所（TWI） The Brooker Medal（アジア から初の受賞) など，数々の学術的な受賞とともに，溶接学会フェローなどを授与されている.

一方, 溶接学会では, 会長, 理事, 監事, 評議員, 編集委員長, 溶接法研究委員会委員長などを歴任し, 特に，平成16年からの 2 年間は会長として溶接・接合工学の発展に尽力した。また，文部省学術審議会専門 委員, 日本学術会議接合工学専門委員会委員長，経済産業省日本工業標準調査委員，発電設備技術検査協会 全自動溶接システム信頼性実証試験委員会委員および分科会主査，同協会原子力発電設備維持に係る技術基 準等検討委員会委員，日本溶接会議理事，同会議第XII 委員会委員長，日本溶接協会理事，同協会溶接棒部会 技術委員会委員長，同協会電気溶接機部会技術委員会委員，国際溶接学会（IIW）副会長，同学会第 XII 委員 会委員長など，数多くの官公庁・学協会・中立機関の委員長や主査を務め，国内外を問わず，溶接界に大き く貢献している.

以上のように，牛尾誠夫君は学問的業績はもとより，その広い識見と優れた人格を持って多年にわたり学 生・後進の指導・教育ならびに溶接工学・技術の発展に多大の貢献をなした功績は極めて高く評価される. 


\title{
溶接・接合プロセスにおける材料挙動の解明と 数理的アプローチによるその最適化
}

\author{
正 員 西 本 和 俊 君
}

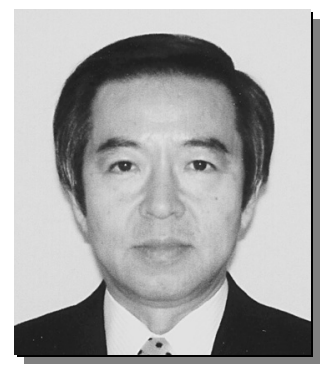

西本和俊君は，昭和 52 年 1 月に大阪大学工学部助手に任ぜられ，昭和 58 年 4 月に 同助教授, 平成 8 年 2 月に同教授に昇任し, 工学部生産加工工学科固相加工学講座 を担当した。その後, 生産科学専攻（大学院重点化）への改組（平成 9 年）および マテリアル生産科学専攻への改組（平成17年）を経て, 現在, 大阪大学大学院工学 研究科マテリアル生産科学専攻, 生産科学コース, 生産プロセス講座, 複合化プロ セス工学領域を担当している。 この間, 同君は学術研究执よび教育に取り組み, 学 生および後進の溶接・接合工学に関する教育・研究指導に努め, 多くの研究者, 技 術者を社会に送り出している.

同君の研究業績は，安定形ステンレス鋼溶接部の耐食性研究から始まり，炭化物 の析出挙動とナイフラインアタック現象の解明では, $\mathrm{Cr}$ 炭化物の析出に起因する発 生機構およびREM 添加によるその改善策を提案し，内外から注目される成果を収めるとともに，ステンレス 鋼溶接熱影響部のウェルドデイケイの発生機構と防止策を究明している。 その後，高純度フェライト系ステ ンレス鋼溶接部の脆化とその改善，二相ステンレス鋼溶接部の相変態と耐食性，ステンレス鋼のレーザ表面 改質，ステンレス鋼溶接部の鋭敏化とその改善，二相ステンレス鋼の $\sigma$ 相脆化，ステンレス鋼の熱脆化とスピ ノーダル分解，ステンレス鋼 FCAW 溶接金属の再熱割れ，ステンレス鋼レーザ溶接部の高温割れ，高公素ス テンレス鋼の高温割れ，ステンレス鋼の亜鉛脆化割れ，スーパーステンレス鋼・超高純度ステンレス鋼の溶 接性などに関する一連の研究を通じて，ステンレス鋼溶接部に扔ける材料挙動を系統的に解明するとともに， ステンレス鋼の溶接治金を体系化している。また，インバー合金多層盛溶接金属の高温割れ，耐熱鋳鋼の補 修溶接割れ，ニッケル合金レーザ溶接部の HAZ 割れ，ニッケル合金多層盛溶接部のミクロ割れ，Cr-Mo 鋼の 補修溶接性，超高張力鋼溶接材料の開発，チタン合金やニオブ合金の溶接性など，広く耐熱・耐食合金掞よ び先進材料の溶接冶金に関する研究にも多大の成果を上げている.

一方，同君は早くから先進材料に対する新しい接合プロセスに関する研究に着手し，超耐熱合金，単結晶 超合金掞よび耐熱鋳鋼の液相拡散接合，ファインセラミックスと金属の接合，ODS 合金のパルス通電焼結接 合， $\mathrm{Zr}$ とステンレス鋼の高信頼異材接合，アルミニウムとステンレス鋼の高性能拡散接合，超微細粒鋼のハ イパー界面接合（瞬間表面溶融圧接）などの先進的界面接合プロセスの開発・確立に向けて，非常に有用な 研究成果を得ているとともに，液相拡散接合の概念を利用した結晶制御合金の液相拡散補修プロセスの開発 も行っている．また，耐熱・耐食材料抢よび異種材料のレーザブレイジングに関する研究は，世界に先駆け て本プロセスの適用性を明らかにした研究成果として内外から高く評価されている。一方，新しい表面改質 プロセスとして，イオンプレーティングによる耐食皮膜形成，マイクロ・スパーク・コーティングによる耐 摩耗皮膜形成に関する研究では, 成膜現象・機構の解明および要求性能を满足するためのプロセスパラメー 夕の最適化を実施している。さらに，レーザによる結晶制御クラッディングの確立に向け，学術的見地と実 用的見地より系統的な研究を実施し，単結晶合金の表面改質・補修プロセスの応用・発展に対しても大いに 貢献している.

溶接・接合に関わる材料学的現象の定量的取り扱いに関する研究では，溶接・接合プロセスにおける材料 挙動のモデリングとシミュレーションに関して広範な検討を行い，溶接・接合部の材料挙動の系統的理解や 体系化拈よびプロセスの最適化に対して新しい方法を提案している．特に，数理的アプローチによる溶接・ 接合プロセスの最適化研究では, 先進的数理手法を駆使した最適化システムを構築し, 溶接・接合材料設計, 最適プロセスパラメータの選定, 施工安全裕度の検証などに適用され，その先進性と有効性について非常に 高い評価を得ている。 また，溶接・接合部の特性予測，経年変化予測やその補修・延命措置などについても 研究するとともに，先進的溶接エキスパートシステムの確立に向け，材料挙動の理解支援システムについて も提案している。

同君は，溶接学会においては，副会長，理事，溶接治金研究委員会委員長，企画委員会委員長，論文査読 委員会委員長をはじめ, 国際溶接学会日本大会実行委員会総務委員長, 国際溶接シシポジウム実行委員長, 全国大会実行委員長，関西支部副支部長など，その他に，編集委員会，教育委員会，財務強化委員会をはじ め多くの委員会幹事・委員などを歴任しているとともに，日本溶接協会では，溶接管理技術者管理委員会委 員長, 特殊材料溶接技術研究委員会委員長, 宇宙機溶接技術研究委員会委員長, H-IIA 特殊工程アセスメント 委員会委員長はじめ，いくつかの委員会幹事・委員を務めている．また，原子力発電設備の溶接・接合技術 に関わる学会や政府関係の各種委員会の主査や委員を歴任するなど溶接界への貢献は多大である.

以上の上うに，西本和俊君は溶接・接合プロセスに扔ける材料挙動の解明，体系化と数理的アプローチに よるその最適化の研究分野において，基礎学理を応用展開した優秀な研究を行い，特に溶接治金研究に関し て多大の成果を上げている。 また，溶接学会や日本溶接協会をはじめ，溶接・接合関連の学協会，政府機関， 委員会などの要職を歴任するとともに，溶接・接合教育，啓発活動にも多大な貢献を行っている. 


\section{水中及び高圧雾囲気中における溶接現象の解明および 溶接プロセスの監視と知的制御}

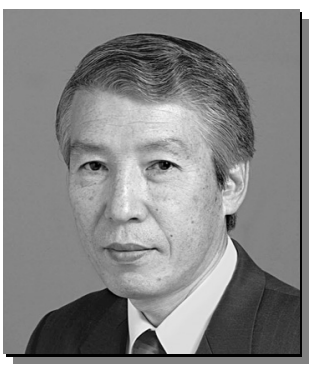

菅泰雄君の主たる研究は，水中及び高圧雲囲気中におけるアーク溶接䇽よび溶接 プロセスの完全自動化を目指した溶接の監視と知的制御に関するものである.

オイルリグやメガフロートなど海洋構造物の組立て・補修において必須の技術で ある水中溶接の研究では，プラズマ溶接をはじめ各種溶接法の水中溶接への適用を 試み，湿式水中アーク溶接の可能性について検討している．また，水中における溶 接アーク現象，溶接割れおよび気孔の発生など水の分解によって生成した水素に起 因する金属学的問題について，その発生メカニズムの解明およびその解決法の提案 などを行っている. 特に, 溶接部の硬化の原因となる溶接部の冷却速度と溶接条件 との関係，拡散性水素の吸収現象，後熱による水素の拡散放出と遅れ割れ発生との

関連などについて，詳細な検討を行っている.

高圧䨌囲気下における溶接の研究では, 高水深における乾式水中溶接を想定して, 被覆アーク溶接㧍よび ティグ溶接を用いて実験的研究を行っている。とりわけ，ティグ溶接では，最大 $5 \mathrm{MPa}$ (50気圧）までの高 圧下で実験を行い，溶接アーク現象に及ぼす圧力の影響，不安定アークの磁界による制御，タングステン電 極の消耗現象などについて詳細な検討を行っており, 溶接アーク物理学の発展に寄与している.

溶接の自動化については, 視覚センサによる溶接線の検出と自動追従制御に関して早くから取り組んでい る. 特に, 溶接線を安定に検出するため, 様々な画像処理手法を提案している. また，溶接トーチ先端が溶 接線上を安定して移動するためのアルゴリズム，アーク長自動制御法等を提案し，その有効性を実験により 確認している．溶接中に溶接状況を直接センシングし，溶接条件を常に最適に保つための適応制御に関する 研究では, 主として視覚により溶融池の形状・寸法をセンシングする制御システムと溶融池の振動を検出し

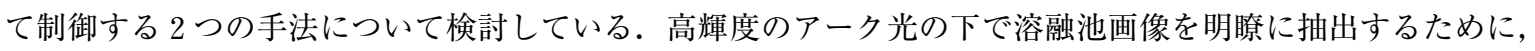
計測方法と画像処理を工夫し, 薄板溶接における溶融池の表面形状から裏ビード幅を推定し制御する手法, 溶接シミュレーションと視覚センサによる測定結果を融合した手法，直接裏側から溶融池を監視する手法な ど様々な手法を提案している．また，水平固定パイプの全周囲溶接システム，平面上移動型溶接ロボットの 開発なども行っている.さらに, 溶融池の監視と振動検出を併用したより高度な溶接制御システムの開発に も取り組んでいる.

溶接分野における画像処理の応用の一つとして，溶接部の放射線透過試験フィルムの自動判定システムの 構築に関する研究を行っている. 不明瞭な欠陥画像を精確に抽出するための画像処理, 久陥の種類を識別す るためのニューラルネットワークや遺伝的アルゴリズムを応用した知的検査システム等の開発を通して, 非 破壊検查の自動化・無人化のためのシステム構築に寄与している.

以上のように，同君は水中及び高圧雲囲気下に扔けるアーク溶接抢よび溶接プロセスの監視と制御の分野 で業績をあげており, これにより軽金属溶接構造協会論文賞, 日本機械学会功績賞, 溶接学会シンポジウム 賞, 国際会議 SCIS\&ISIS2004 Best paper award を受賞している.また, 溶接学会では軽構造接合加工研究委 員会委員長, JAAA シンポジウム 2005 組織委員長, アーク物理研究委員会幹事長, 論文查読委員会委員, 評 議員を歴任しており, また日本機械学会機械材料・材料加工部門長, 摩擦圧接協会副会長, 日本非破壊検査 協会画像処理技術専門委員会委員長, Member of Technical Program Committee of ISOPE な゙゙務め, 溶接・ 材料加工・検査分野に打いて大きく貢献している. 


\title{
ろう付並びに固相接合法による界面接合の研究および 接合現象の材料組織学的解明
}

\author{
正員 渡辺健彦君
}

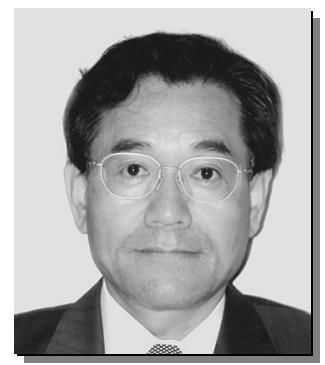

渡辺健彦君の主要な研究は, ろう付や超音波あるいは回転プローブを用いた固相 接合法による同種材料や異種材料の界面接合の研究およびその接合機構や接合部の 特性に及ぼす接合因子について材料組織学的な観点から考察した研究であり，この 分野において優れた成果を挙げている.

ろう付関係の研究では, 新材料として期待されるマグネシウム合金のろう付研究 において顕著な業績を挙げている．すなわち，AZ31B 等のマグネシウム合金展伸材 のろう付はこれまで不可能であったが，低融点ろう材および低温で表面酸化皮膜を 除去できるフラックスを開発してマグネシウム合金展伸材のろう付を可能にしてい る。また，マグネシウム合金のろう付性や固相接合性を向上させるための表面処理 法としてハロゲン表面処理法を考案して表面皮膜の薄膜化を可能にしている。この 研究によって，マグネシウム合金のろう付が容易に可能になり今後の応用が期待されている.

アルミニウム合金のろう付においても顕著な業績を挙げており，これまで，ろう付が困難であった高マグ ネシウム含有アルミニウム合金を大気中で無フラックスでろう付できる超音波併用ろう付方法を開発すると ともにろう付部の材料組織学的解析を行ってその接合過程を明らかにしている.さらに，本手法をアルミニ ウム合金と銅の異材接合にも展開することによって接合強さを改善できることも明らかにしている．加えて， 同手法をステンレス鋼の銀ろう付に適用することによっても接合強さが大幅に向上することを示し，接合強 さの向上機構を材料組織学的に解明している.

また，チタンのろう付研究に関して，ろう付部特性に及ぼす雾囲気の影響の解明，また，高性能の銀基ろ うの開発，および，超音波振動を併用することによって低温・短時間でろう付部の高性能化が可能になるこ とを明らかにしている。

超音波接合関係の研究では，異種材料および同種材料の超音波接合部の特性に及ぼす接合因子の影響を材 料組織学的に解明している。すなわち，異種材料の超音波接合研究では，接合強さに及ぼす材料の硬さや熱 伝導性および接合面の表面粗さと表面処理法の影響を明らかにし，さらに，表面処理法と関連した表面酸化 皮膜の挙動を詳細に解析して接合因子の影響や接合過程を明らかにしている。また，アルミニウムとアルミ ナセラミックスに超音波接合法を適用してその接合に成功しており，さらに，その接合界面での化学結合状 態をオージェ分析して，界面では $\mathrm{Al}$ と O との化学結合が生じていることを明らかにしている.

さらに，同種材料の超音波接合の研究では，超音波接合が困難とされていた高マグネシウム含有アルミニ ウム合金について，その理由を材料組織学的に解明している.さらに，その超音波接合を可能にする新しい 手法を示して高い評価を得ている。すなわち，高マグネシウム含有アルミニウム合金を超音波接合すると， 接合面に $\mathrm{Mg}$ が偏析するために接合が困難であることをオージェ分析で明らかにし，さらに，その超音波接 合性を改善する方策として，接合界面にエタノールを付着させる手法を提案した．エタノールの存在によっ て接合面での相対運動の活性化および温度上昇が顕著になり，接合面の塑性変形量が増加して接合性が向上 することを明らかにしている。

回転プローブを用いた異種金属材料の固相接合関係の研究では，回転プローブを軟らかい方の金属内に挿 入後，硬い方の金属の接合面に接触させて接合面の酸化皮膜を除去して活性面を露出させ，そこへ塑性流動 状態にある軟らかい方の金属を凝着させて異種金属間の接合を達成する界面活性化凝着接合法を考案してい る.この方法で，溶融溶接が困難な鉄鋼とアルミニウム合金，鉄鋼とマグネシウム合金やチタンとマグネシ ウム合金等の突き合わせ接合を可能にし，その接合機構や接合因子について材料組織学的に解析して高い評 価を得ている．同様の手法を鉄鋼とアルミニウム合金の異種材料の重ね合わせ継手にも適用してその有用性 を明らかにしている。

この他，溶接治金学分野においても優れた成果を挙げており，溶接熱影響部における高温粒界割れ発生機 構の解明，高張力鋼溶接熱影響部における水素による割れと部分溶融現象との関連性の解明，パルスティグ や電磁擋拌作用を用いた溶接金属部結晶粒の微細化研究，ステンレス鋼溶接熱影響部および溶接金属部にお ける結晶粒界の挙動についての結晶学的解析等，溶接・接合に伴う接合部の挙動を首尾一貫して材料組織学 的な観点から解析しており，有用な情報を発信して高い評価を受けている.

溶接学会では，評議員，界面接合研究委員会委員長，論文査読審査委員会副委員長，溶接治金研究委員会 幹事をはじめ, その他, 溶接学会東部支部幹事, 教育委員会, 学会拡充推進委員などの多くの委員会委員な どを歴任している。また，日本溶接協会では，貴金属ろう部会先端材料接合委員会委員長，貴金属ろう部会 業務委員会ぶれいず編集委員，チタン溶接 WG 主査をはじめ，その他，広報出版委員会員等の委員を歴任し ており，溶接界への貢献は多大である。

以上のように，渡辺健彦君の業績は溶接関連分野の発展に大きく貢献している. 


\title{
佐々 木 賞
}

\section{溶接材料の進歩、発展ならびに後進の 指導・育成に貢献した功績}

\author{
正員 菅哲 男 君
}

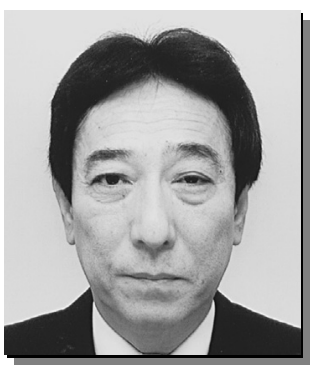

大きく寄与した.

(2) メタル系フラックス入りワイヤ「MX シリーズ」の開発・実用化

ソリッドワイヤの特長（低スラグ）を生かしつつF CW の高能率性と良好な溶接作業性を有する新たな成分 系の FCW を世界に先駆けて開発した。すなわち，金属粉を主体とする新しいフラックス組成と外皮金属の化 学組成（C 量の最適化）及び特殊なアーク安定剂を見出し，画期的なメタル系 FCW（MXシリーズ，炭素鋼 用）を開発・実用化した（昭和61年)。これにより，FCWが造船以外の業種（鉄骨，建機など）に拡大した。

(3) 低ヒューム・低スパッタフラックス入りワイヤ「Z シリーズ」の開発・実用化

従来 FCW（DW シリーズ，MX シリーズ）の特長を維持しつつ，ヒューム及びスパッ夕の発生量を大幅に 低減させた「低ヒューム・低スパッ夕 $\mathrm{FCW}(\mathrm{Z}$ シリーズ，炭素鋼用）を開発・実用化した (平成 7 年)。低 ヒューム化の技術 [上記 (1)] に加えて，外皮金属の成分調整やフラックス組成の最適化（アルカリ金属の添

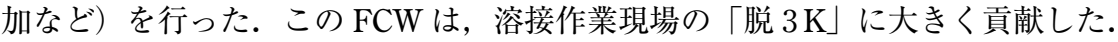

(4) 高性能銅めっきなしソリッドワイヤ「SE シリーズ」の開発・実用化

ソリッドワイヤの送給性を抜本的に向上させた「高性能銅めっきなしソリッドワイヤ」（SEシリーズ，炭 素鋼用）を開発・実用化した（平成13年)。良好なワイヤ送給性は，銅めっきに替わるワイヤ表面処理技術 $\left(\mathrm{MoS}_{2}\right.$ などの塗布 $)$, 新伸線方法などの新技術の開発により達成した。このソリッドワイヤは, ロボットによ る溶接の自動化が進んでいる業種（鉄骨，産機など）での能率向上に寄与した.

以上のような炭素鋼用溶接材料に関する新商品・新技術に対する貢献は高く評価され，同君は，大河内記 念会・平成 5 年度大河内記念技術賞，日本溶接協会・昭和 59 年度技術賞，発明協会・平成元年度近畿地方発 明表彰奨励賞などを授与されている。なお，「溶接ヒュームに関する研究」で，工学博士を取得している.

また同君は，溶接学会理事，同東部支部評議員・幹事，同溶接法研究委員会副委員長・幹事長，日本溶接 会議理事，日本溶接協会評議員，同溶接棒部会技術委員会幹事長，日本溶接棒工業会理事などの職務を務め, その活動は一企業内に止まることなく，わが国の溶接界全体に幅広く貢献している．なお，産・官・学の連 携強化にも尽力し，多くの溶接関連の連携協定締結において実績を残した.

以上のように，同君は，溶接材料に関する研究開発で顕著な業績を残し，溶接技術の進歩発展に大いに寄 与した。また，経歴の職位にあって後進技術者を的確に指導・育成し，多くの業績を残さしめた。更に，溶 接学会, 日本溶接協会などの公的な活動を通じ, 溶接界全体のレベルアップにも積極的に尽力し, 功績は多 大である。

昭和 25 年 2 月 9 日生

昭和 49 年 3 月 名古屋工業大学大学院工学研究科 金属工学専攻 修士課程修了 昭和 49 年 4 月 (株)神戸製鋼所入社＼cjkstart溶接棒事業部技術部配属

昭和61年 1 月 同部 主任研究員

平成 8 年 4 月 溶接事業部技術部 専門部長

平成12年 4 月 溶接カンパニー 技術開発部長

平成 13 年 4 月 溶接カンパニー 技術開発部長 兼溶接カンパニー 藤沢事業所長

平成15年 4 月 溶接カンパニー 執行社長補佐

平成 15 年 7 月 溶接カンパニー 研究首席

平成16年 6 月＼cjkstart神鋼溶接サービス(株) 常務取締役 技術調査部長

現在に至る 


\title{
アーク溶接機・プラズマ切断機の開発·普及 ならびに後進の指導・育成に貢献した功績
}

\author{
正員 原田章 二君
}

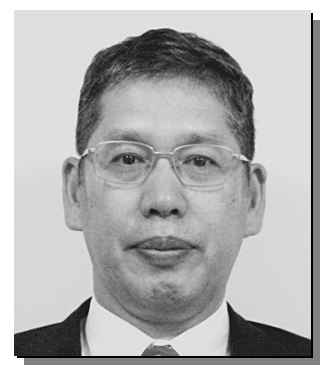

原田章二君は昭和 51 年大阪大学大学院工学研究科溶接工学専攻を修了後, 直ちに 株式会社ダイヘンに入社し, 以後溶接・切断機器の研究開発部門および企画部門に おいて, 数多くの新溶接法及び新溶接電源・機器の企画並びに開発を行い，この分 野の進歩, 発展, 向上に寄与してきた。 また，知的制御溶接電源開発の技術者の指 導・育成に尽力し，グローバル化の中で我が国の溶接電源が国際的に信頼を得るこ とに貢献した。この間の功績は非常に大きい.

同君はこれらの開発に当たって, 卓越した洞察力と斬新なアイデアにより溶接現 場ニーズを取り入れた多くの業績をあげた。特に, マイコン制御技術を溶接プロセ 又制御にいち早く応用し，炭酸ガス/マグ溶接機ではワイヤ径，シールドガス組成 ならびに溶接電流に応じて最適な溶接電流波形が得られる電子リアクトル制御を開発してアーク安定性を飛 躍的に改善し，ロボット溶接をはじめとする溶接の自動化に貢献した。また，初心者でも熟練工の感性に近 い高品質で安定な溶接ができるファジイ制御アルミニウムミグ溶接機および炭酸ガス/マグ溶接機, ミグ溶 接でありながらティグ溶接並の高品質溶接を実現させた低周波パルスミグ溶接機，低入熱で薄板の溶接を可 能にした交流ミグ/マグ溶接機を相次いで開発・実用化した，そして，これらの成果を国内のみならず，IIW をはじめとする国際会議において数多く発表するなど，溶接電流波形制御技術の普及に努めた.

これらの業績に対して, 平成 5 年には “ファジイ制御 MIG 溶接機の開発と実用化”で，『日本溶接協会技 術賞』が授与されている. また, 平成 6 年には “低周波パルス MIG 溶接法の研究”で『軽金属溶接構造協会 論文賞』が授与されている.さらに，平成13年には “パルス MAG 溶接方法及び装置”で『日本溶接協会注目 発明賞』, 平成16年には『発明協会大阪支部発明大賞優秀賞』が授与されている.

またこの間, エアプラズマ切断機の国産化をはかり, 小電流から大電流のエアプラズマ切断機の製品化を 進め普及に努め，わが国の金属切断作業の高能率化，高品質化に貢献した役割も特筆される.

一方, 同君は以上の業績に加えて, 溶接学会においては, 評議員, 理事, 関西支部常任幹事, 溶接アーク 物理委員会幹事, 溶接法研究委員会主査, 編集委員, 論文查読委員を務めた. 日本溶接協会では総務委員, 財務委員, 大阪支部理事, として, また, その他多くの溶接関連団体の役員として溶接界全体の発展のため に長年にわたり尽力してきた，さらに，神戸大学の非常勤講師として溶接機器の講義を担当し，また職業能 力開発大学校の離職者訓練カリキュラム検討委員（溶接関連）を務めるなど，雇用促進においても意欲的な 活動を行い，後進技術者の指導育成に貢献してきた。これらの功績はきわめて顕著である.

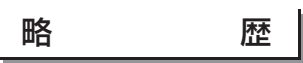

昭和 26 年 2 月 16 日生

昭和51年 3 月 大阪大学大学院工学研究科溶接工学専攻 修了

昭和51年 4 月 大阪変圧器株式会社（現, 株式会社ダイヘン）入社

溶接機事業部 研究部配属, アーク溶接機及び溶接法の研究開発の業務

昭和61年 7 月 研究開発部課長

平成 4 年 7 月 研究開発部次長

平成 8 年 7 月 ダイヘンスタッド株式会社＼cjkstart取締役技術部長

平成11年 4 月 株式会社ダイヘン企画部 CS 担当部長

平成16年 7 月 ダイヘン溶接メカトロシステム株式会社 取締役 CS 担当

平成17年 7 月 株式会社ダイヘン理事，ダイヘン溶接メカトロシステム株式会社取締役CS担当

平成18年 7 月 ダイヘンスタッド株式会社代表取締役社長

現在に至る 


\section{$\mathrm{BaTiO}_{3}-\mathrm{SrTiO}_{3}$ 積層薄膜の誘電特性}

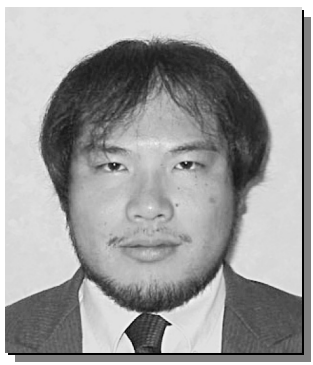

日 野 孝 紀 君

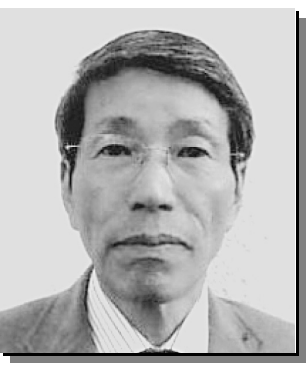

西田稔 君

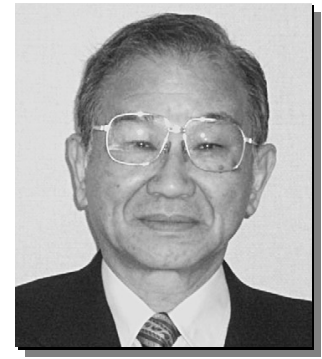

荒 木 孝 雄 君

$\begin{array}{llllll}\text { 正 } & \text { 日 } & \text { 野 } & \text { 孝 } & \text { 紀 } & \text { 君 } \\ \text { 正 } & \text { 員 } & \text { 田 } & & \text { 稔 } & \text { 君 } \\ \text { 正 } & \text { 員 } & \text { 荒 } & \text { 孝 } & \text { 雄 } & \text { 君 }\end{array}$

$\mathrm{BaTiO}_{3}$ 誘電体材料は，現在メモリカード，IC カードの不揮発メモリ，積層セラミ ックスコンデンサ（MLCC; Multi Layer Ceramics Capacitor）等，広く利用されてお り，構成材料の単位体積あたりの誘電特性向上を目指した研究開発が世界中で行わ れている.MLCC は，小型情報通信機器に対する利便性を向上させる「携帯性」な らびに多機能性, 高速通信, 高密度記憶等の「スマート化」への要求によって膨大 な規模の市場を有している．従来から MLCC の作製に用いられている粉末焼成技術 は，多段長時間を有しており，次世代に向けた研究開発の高効率化及び製品の極小 化に対応した技術革新が必要とされている。これまでの焼成技術にて作製する MLCC の薄層化技術に対し，薄膜作製技術でのボトムアップ技術による薄膜コンデ ンサは，物理的あるいは化学的な蒸着にて容易に作製しうるものの，誘電特性が劣 るとされている.

本論文では，固体を分子や原子レベルにまで分解し，基板上で順次堆積成長しな がら薄膜を形成する PLD（Pulsed laser deposition）法を用い， $\mathrm{BaTiO}_{3}-\mathrm{SrTiO}_{3}$ 積層薄 膜を作製することによって誘電特性に及ぼす積層周期の影響について検討し，また 積層条件の最適化を行うことで薄膜合成設計法を確立した．さらに $\mathrm{BaTiO}_{3}$ と $\mathrm{SrTiO}_{3}$ のへテロ接合において，同じ構造を有する場合にミスフィットが大きな組み合わせ でもエピタキシャル成長が認められ，人工界面の結晶方位のなかでミスフィットが 大きくなる [111］方向にも超格子構造を有する薄膜を作製できることを明らかにし た．その際，ミスフィットによって（111）面平行に圧縮され，膜厚方向である基板 に垂直な [111］方向に格子が伸びた菱面体晶のような状態で成長することになり， 人工的に [111] 方向に格子が伸びた結晶の分極特性を知ることができる. 本プロセ スによれば，単層膜を積層化することにより，薄膜内部の界面の数を制御すること が可能となり，界面でのひずみ誘起効果を応用した積層薄膜の誘電率は，積層単位 が小さいほど大きくなることを明らかにした，その結果，積層条件の最適化によっ て，現状の焼成技術にて作製された 1005 サイズ MLCC の容量密度に比べて約一桁大 きい值を有する薄膜コンデンサの試作に成功した.

以上のように，本論文は，MLCC の基本性能を左右する誘電体層の高速開発技術 として，エキシマレーザーを用いた PLD 法による $\mathrm{BaTiO}_{3}-\mathrm{SrTiO}_{3}$ 積層薄膜の合成と 誘電特性について系統的な研究を行うことで従来製法では達成困難な優れた誘電特 性を実現しており, さらに本プロセスはナノ構造制御技術の分野への展開が今後, 大いに期待できる。

略歴

日 野 孝 紀

1971 年 8 月 22 日生

1999 年 3 月 愛媛大学大学院 理工学研究科 生産工学専攻（博士後期課程）修了

1999 年 3 月（博士）工学の学位を愛媛大学より受ける。

1999年 4 月 財団法人四国産業技術振興センター 博士研究員

1999年10月 工業技術院四国工業技術研究所 基盤技術部 博士研究員

2000 年 4 月 新居浜工業高等専門学校 助手 (材料工学科)

2007 年 4 月 新居浜工業高等専門学校 講師（環境材料工学科） 
西田稔

1944 年 4 月 28 日生

1969 年 3 月 大阪大学大学院工学研究科溶接工学専攻 (修士課程) 修了

1969 年 4 月 愛媛大学 助手 (工学部 治金学科)

1985 年 4 月 愛媛大学 講師（工学部 金属工学科）

1992 年 2 月 工学（博士）を大阪大学より受ける

1994 年 2 月 愛媛大学 助教授 (工学部 材料工学科)

2006 年 4 月 愛媛大学大学院 助教授（理工学研究科 物質生命工学専攻 機能材料工学コース）

2007 年 4 月 愛媛大学大学院 准教授（理工学研究科 物質生命工学専攻 機能材料工学コース）

荒 木 孝 雄

1941 年11月23日生

1969 年12月 大阪大学大学院工学研究科溶接工学専攻（博士課程）修了

1969 年12月工学博士の学位を大阪大学より受ける

1970 年 4 月 ドイツ・ハノーバ工科大学材料研究所 客員研究員（ドイッ・アレキサンダー・ フォン・フンボルト財団の招聘による)

1972 年 7 月 大阪大学 助手 (工学部 溶接工学科)

1974 年 8 月 大阪大学 助教授 (工学部 溶接工学科)

1989 年 6 月 愛媛大学 教授 (工学部 機能材料工学科 (現))

2005 年 4 月 愛媛大学 評議員, 愛媛大学産業科学技術支援センター長

2006 年 4 月 愛媛大学大学院 教授（理工学研究科 物質生命工学専攻 機能材料工学コース）

2007 年 4 月 愛媛大学名誉教授 
過共析鋼溶融過程における相変態の in-situ 観察

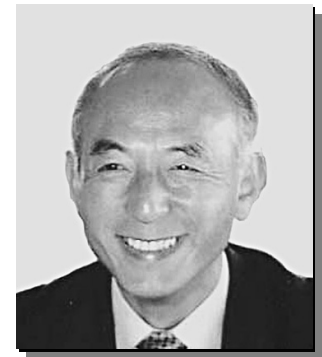

小 溝 裕 - 君

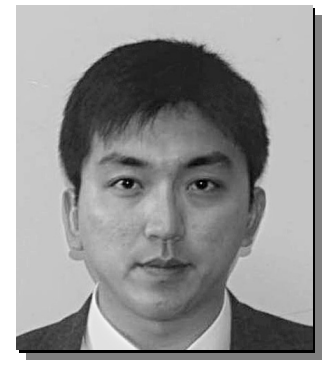

寺 崎 秀 紀 君

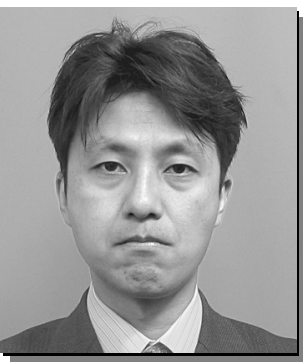

米 村 光 治 君

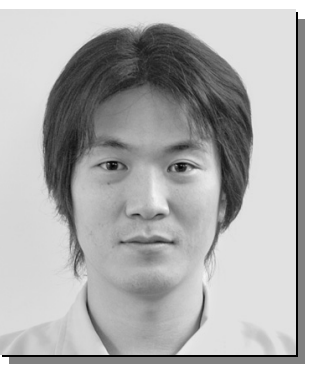

小 薄 孝 裕 君
本論文は溶接過程における材料の相変態をその場で観察する手法に関するもので ある.アーク溶接やレーザー溶接において, 溶接金属部では材料が加熱され溶融し, 液相状態を経て凝固した後，相変態や析出がおこる．また，溶接熱影響部（HAZ） では融点までは加熱されないまでも，高温に加熱された後，同じく相変態や析出が 起こることは良く知られている。このように溶接中の治金現象のほとんどが高温現 象である。これまで材料の組織的変化を調べるため, いろいろな手法が考えられて きたが，それらの多くは, 試料をある温度に加熱し, 冷却中の所定の温度から急冷 して，その温度における組織状態を凍結して，室温に冷えてから組織を観察すると いうものである。しかし，いくつもの温度からの急冷を繰り返し行わなければなら ず，非常に手間がかかるという問題がある.

本論文では，溶接中の組織変化を直接観察し，評価したいという要求に応えるた め，高輝度の第三世代放射光を用いて，アーク溶接時の一方向凝固過程をその場観 察する手法を，世界に先駆けて確立した。高時間分解 X 線回折法により，急速加 熱・急速冷却時の溶融－凝固－変態過程を捉えることに成功した。さらに，高温レ ーザ顕微鏡による実空間形態的観察と組み合わせることにより，溶接過程における 相変態をin-situ観察する手法を開発した。この手法を用いて，炭素鋼の相変態挙動を 議論した。これまで傍証に基づく推察により議論していたことが，実際目で見た上 で議論できるようになった。これにより, 初晶の生成状況や第二相の晶出夕イミン グなどから，溶接時の組織制御が可能となるばかりでなく，広く核生成や結晶の成 長機構の研究に応用できるなど, 今後の材料研究に与える影響は非常に大きいもの と考えられる.

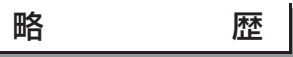

小 溝 裕 一

昭和 25 年 2 月 17 日生

昭和 47 年 3 月 京都大学工学部金属加工学科卒

昭和 49 年 3 月 京都大学大学院工学研究科修士課程修了

昭和 49 年 4 月 住友金属工業(秼入社

昭和 61 年 4 月 住友金属工業(株)中央技術研究所主任研究員

平成 8 年 7 月 住友金属工業(株)総合技術研究所部長

平成13年 7 月 住友金属工業(侏総合技術研究所副所長

平成 16 年 3 月 大阪大学接合科学研究所教授

現在に至る

寺 崎 秀 紀 昭和 48 年 6 月 19 日生

平成10年 3 月 名古屋工業大学機械工学科卒

平成15年 3 月 大阪大学 大学院工学研究科 生産科学専攻博士後期課程修了

平成15年 4 月 シドニー大学電気情報工学科リサーチアソシエイト

平成16年 4 月 大阪大学接合科学研究所特任研究員 
平成18年 8 月 大阪大学接合科学研究所助教

現在に至る

米村 光 治

昭和 45 年 1 月 29 日生

平成 4 年 3 月 広島大学理学部物性学科卒

平成 6 年 3 月 広島大学大学院理学研究科物性学専攻博士課程前期修了

平成 6 年 4 月 住友金属工業(株入社

平成17年 4 月 住友金属工業(株)総合技術研究所主任研究員

現在に至る

小薄 孝 裕

昭和53年 2 月 13 日生

平成 12 年 3 月 大阪大学工学部 環境エネルギー工学科卒

平成 14 年 3 月 大阪大学大学院工学研究科 原子力工学専攻博士前期課程修了

平成14年 4 月 住友金属工業（株）入社

現在に至る 


\section{YAGレーザ・TIGアークハイブリッド溶接現象の解明}

\section{（第1 報〜第4報）}

$\begin{array}{llllll}\text { 正 } & \text { 内 } & \text { 藤 } & \text { 恭 } & \text { 章 } & \text { 君 } \\ \text { 正 員 } & \text { 水 } & \text { 谷 } & \text { 正 } & \text { 海 } & \text { 君 } \\ \text { 正 員 } & \text { 片 } & \text { 山 } & \text { 聖 } & \text { 二 } & \text { 君 }\end{array}$

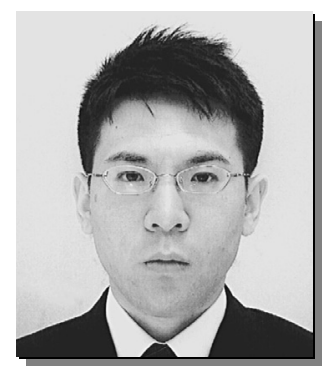

内 藤 恭 章 君

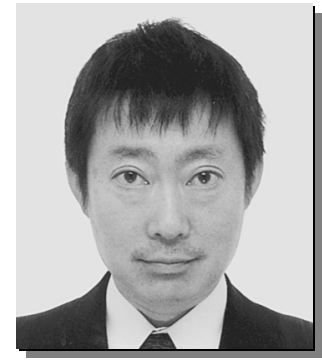

水 谷 正 海 君

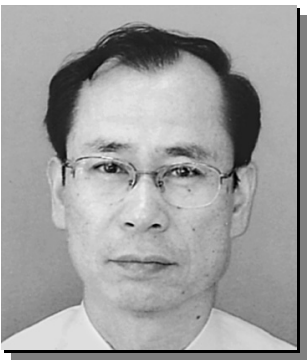

片 山 聖 二 君
最近，レーザとアークを組み合わせたハイブリッド溶接法が，それぞれの溶接法 の欠点を補完して, 溶込み深さの増大, 溶接速度の増加, 開先ギャップ裕度の拡大, ポロシティの低減などに効果があることが報告され，高速・高効率・高品質な溶接 法として注目されている。しかしながら，ハイブリッド溶接現象やアーク挙動，溶 接部の形成機構と湯流れの関連性，溶接性に及ぼす大気成分やシールドガスの影響, 溶接欠陥であるポロシティの低減・防止機構などについてはほとんど解明されてい ない.

そこで，本論文では，ハイブリッド溶接現象の総合的な理解と把握を目的とし， YAG レーザと TIG アークを用いて，イオウ（S）含有量の少ないオーステナイト系 ステンレス鋼 SUS 304 に対して TIG アーク先行またはYAG レーザ先行のハイブリッ ド溶接を系統的に行い, 高速度ビデオやマイクロフォーカス X 線透視リアルタイム 観察法および創意工夫した実験により，ハイブリッド溶接現象，溶融池内部の湯流 れと溶接部形状の形成機構，ポロシティの低減機構などを解明している.

まず，溶込久深さと溶融部の形状に及ぼす各種溶接条件と周辺雲囲気の影響につ いて検討し，溶込久深さと形状は，レーザのパワー密度，アーク電流㧍よび雲囲気 中の酸素ガス割合の影響を顕著に受けることを明らかにしている．溶融部上部の溶 込み形状が変化する原因に関しては, 表面張力対流とガス気流の影響が大きいこと を明らかにしている。

従来，ハイブリッド溶接時における深溶込み溶接および高速度溶接が可能な理由 として, 溶接時のアーク・プラズマがキーホール内部に侵入して底部にまで達し, 高効率化が達成されているという説があったが, 特別に考案した試験片と高速度ビ デオ観察法を用いて実験的検討を行い，溶接時のアークは，キーホール口近傍に集 中し，キーホール内部に侵入しにくく，先端底部にまで到達していないことを明ら かにしている。そして，ハイブリッド溶接時において生じる対流熱輸送の効果に着 目し，高速度ビデオとX 線透視リアルタイム撮影装置を用いて，溶融池表面と内部 の様子を可視化し，溶接部の断面形状は，レーザ照射時の蒸発反跳力，プラズマ気 流，表面張力㧍よび電磁対流によって生じる湯流れによって決定されること，そし て，ハイブリッド溶接時の湯流れは，レーザ溶接時と異なり，そしてアーク電流值 によって大きく異なり，その結果として，溶融部の形状が形成されていることを示 している。また，TIGアーク先行または YAG レーザ先行においてレーザとアークの 狙い位置によって溶込み形状が大きくことなることを示し，深溶込みは，アーク単 独溶接時に生成した溶融池位置にレーザを照射し，レーザエネルギーが有効に利用 され，さらに，キーホール口周辺にアークが集中して電磁対流が起こった場合に得 られることを示している.ささらに, 高電流の条件でポロシティが少ない理由は, ア ークカで溶融池表面が凹むことによってキーホール形状が焦点はずしの条件となっ て安定化し，気泡の発生がないためであることを明らかにしている.

以上のように，本論文は，対流熱輸送による溶融部形状の形成メカニズムと欠陥 防止機構を明らかにしており，レーザ溶接および八イブリッド溶接技術の発展に重 要な指針を与え，生産科学・ものづくりの分野に寄与するところが大きい. 


\section{略歴}

内 藤 恭 章

1977 年 6 月 5 日生

2000 年 3 月 大阪大学 工学部 機械系 卒業

2002 年 3 月 大阪大学大学院 工学研究科 機械物理工学専攻 修士課程修了

2006 年 3 月 大阪大学大学院 工学研究科 機械物理工学専攻 博士課程修了

2006 年 8 月 新日本製鐵株式会社 入社.

接合研究センター 勤務

工学博士

水 谷 正 海

昭和34年 7 月 10 日生

昭和 53 年 大阪大学溶接工学研究所（現：接合科学研究所）入所

平成 8 年 大阪大学技術専門職員 接合科学研究所

現在に至る

片 山 聖 二

1951 年 2 月 12 日生

1980 年 12 月 大阪大学博士課程修了（溶接工学専攻）工学博士（大阪大学）

1981 年 1 月 大阪大学溶接工学研究所 · 助手

1997 年 1 月 大阪大学接合科学研究所 ・ 助教授

2002 年 11 月 大阪大学接合科学研究所 - 教授（協力：機械工学専攻)

現在に至る 


\title{
液相拡散接合プロセス最適化システムの開発 （第 1 報，第2報及び第3報）
}

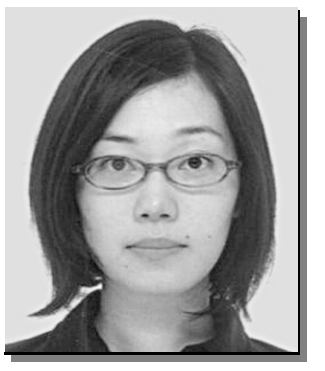

液相拡散接合は，ろう付および固相拡散接合の長所をあわせもった接合方法であ る. 従来，主として付加価值の高い $\mathrm{Ni}$ 基超耐熱合金のタービンブレードなどの接合 方法として採用されていたが，近年，鉄鋼，ステンレス鋼，Ti 合金， $\mathrm{Al}$ 合金などへ もこの接合方法が適用され，適用範囲が拡大している．液相拡散接合に扔いて問題 となるのは，接合継手が目的の機能を有するための，最適なインサート金属の選択 ならびに最適接合条件の把握である.多くの研究では，これらを試行錯誤ならびに 経験則を活かして多くの実験を行うことにより決定していた。そこで，できるだけ 実験量を減らした合理的な最適インサート金属の合金設計ならびに最適接合条件の 選択方法の開発が望まれていた。

本論文では，従来，液相拡散接合の分野で取り入れられていなかった最適化手法に果敢に取り組み，第 1 報では，インサート金属合金設計とプロセスパラメータの最適化を一貫して実施できる新しいベイジアンエ キスパートシステムを構築し，最適值の選択を迅速かつ高速に行えることを明らかにしている．第 2 報及び 第 3 報では，このシステムを用いて $\mathrm{Ni}$ 基超合金 IN738LC，Inconel 718 の液相拡散接合に適用し，インサート 金属合金設計及びプロセスパラメータ（接合温度，接合時間）の最適化を行い，本システムを用いて，良好 な接合継手が得られることを検証している.

以上のように，本論文で開発されたインサート金属合金設計とプロセスパラメータの最適化を一貫して実 施できるべイジアンエキスパートシステムでは，できるだけ実験量を減らした合理的な最適インサート金属 の合金設計ならびに最適接合条件の選択が行え，かつ経験則をできる限り排除し，誰でも迅速に最適インサ 一ト金属の選択ならびに最適接合条件の把握を可能にするものであり，液相拡散接合法の最適化システムと して有用性が高いと評価できる。このようなことから，本論文は，学術的，工業的な価值が高く，溶接工 学・溶接技術への貢献は多大であり, 今後の研究のさらなる発展も大いに期待されるところである.

\author{
略歴 \\ 昭和 52 年 10 月 7 日生 \\ 平成14年 3 月 大阪大学大学院工学研究科生産科学専攻修士課程前期 卒業 \\ 平成14年 4 月 石川島播磨重工業株式会社技術開発本部入社 \\ 現在に至る
}




\title{
金属蒸気混入時のヘリウムガスタングステンアークの プラズマ特性
}

\author{
正員田代真一君
}

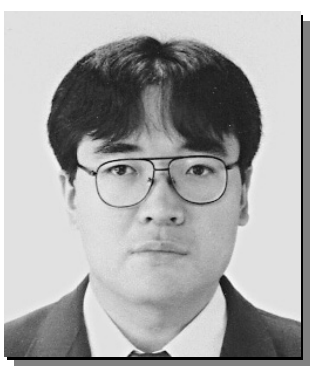

プラズマ特性に及ぼす影響の基礎的評価として, 溶滴の形成，離脱および移行か らなる一連の複雑な現象を避けて，金属蒸気がプラズマ全体に均一に混入したと仮 定した場合の，ヘリウム Gas Tungsten Arc（GTA）のプラズマ特性について数值解 析による仮想実験を行っている.

その結果，金属蒸気混入率の増加に伴い，プラズマの放射熱損失が促進されると 共に電気伝導度も上昇し, 特にアーク柱周辺部や陽極近傍に扔いて, 純へリウムの 場合と比較して大幅な温度低下をもたらすことが示された.

同時に，この放射熱損失はサーマルピンチ効果と同様にアーク柱の緊縮を引き起 こし，プラズマの最高温度を上昇させることを示している.

さらに，金属蒸気の混入が微量である場合，電気伝導度の上昇の影響により入力電力は低下するが，これ が多量となる場合には，プラズマの放射熱損失の影響が支配的となり，これを補うために入力電力は増加傾 向に転じるとともに，熱効率が大幅に低下することを明らかにしている.

以上の上うに，本研究は金属蒸気が溶接プロセスに及ぼす影響を明らかにしたものであり，学術的・工業 的にも価值は高く，今後の研究の更なる発展が大いに期待されるものである.

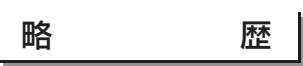

昭和46年10月16日生

平成 8 年 3 月 湘南工科大学工学部電気工学科卒業

平成10年 3 月 中央大学大学院理工学研究科電気電子工学専攻博士前期課程修了

平成17年 3 月 中央大学大学院理工学研究科電気電子工学専攻博士後期課程修了

平成17年 4 月 大阪大学接合科学研究所特任研究員

現在に至る 
建築鉄骨における2継手同時溶接施工技術の開発

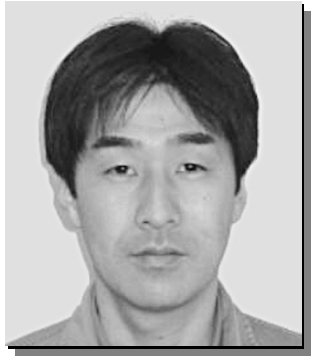

松 村 浩 史 君

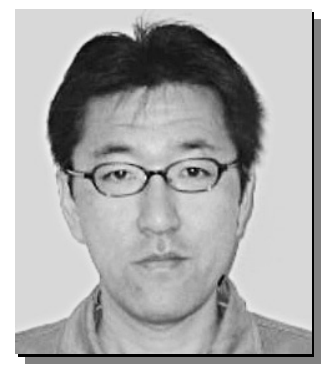

定廣 健 次君

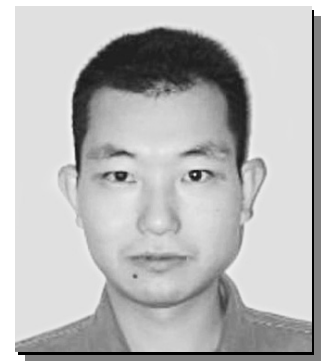

高田篤人君

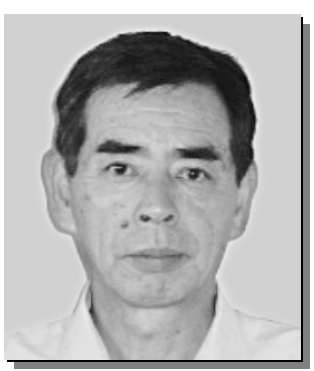

曽 賀 光 郎 君

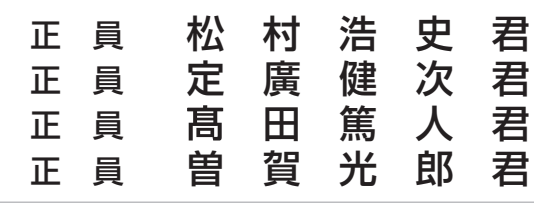

建築鉄骨向溶接ロボットは 1980 年代後半から商品化が加速し，主に角形鋼管柱の 工場内溶接用設備として広く用いられるようになった。最近では鉄骨製作の重要な 設備として，中大手鉄骨ファブリケータの約 $2 / 3$ が溶接ロボットを保有していると いう調查結果もある。しかし，近年，ロボット保有率が高まる一方で，阪神大震災 以降の建築基準法改正で, 鉄骨溶接への品質管理要求は厳しさを増し, 作業コスト 増や納期圧迫の要因となり, 更なる生産性向上とコストダウンを実現できる高能率 な溶接ロボットは鉄骨ファブリケータの大きなニーズとなっていた.

一方，角形鋼管柱のロボット溶接は，ルートギャップや板厚の違いにより継手毎 に溶着金属量が異なるため, 個々に溶接条件を変える必要があり，なおかつ，ポジ ショナとの連動溶接を行う必要があるため, 従来, 多関節型ロボットを用いたシス テムでは柱 1 本当たりロボット 1 台（トーチ 1 本）というシステム構成となってい た．よって，さらに生産性を高めるためには同様のシステムを追加することとなる が，限られたスペースに柱溶接向けの大きなシステムを増設することは容易なこと ではなく，導入コストもシステム数分必要となり高額な投資が必要という問題があ った.

そこで候補者らは，溶着金属量が異なる 2 継手に対し，ワイヤ送給速度に差をつ けることで溶接時間を合わせ，ポジショナ連動溶接が必要な継手をロボット 2 台で 同時溶接する「 2 継手同時溶接施工技術」の開発に取り組んだ。開発にあたって, 現物の寸法精度の実態にあった技術を確立するため, 独自の市場調査を行い, ルー トギャップのばらつきの実態が $4 \mathrm{~mm}$ 程度であることを掴み，このルートギャップ 差を許容することを目標とした。この大きな適用範囲を実現するため, 多層盛溶接 の中で各々のパスで溶接条件の許容範囲に差があることに着目し，溶け込み深さや コーナ部での溶融プールの動きなどを実験により確認した上で，各々のパスで使用 できる溶接条件範囲を求め, 単一のパスではなく複数パスでの溶着金属量の和によ って最終的な余盛量を合わせる本施工方法を確立した。本技術は，従来のロボット 1 台の溶接時と変わらない継手精度での溶接を実現したもので，生産性向上，コス 卜低減，設置スペース極小化などの利点をもつ本技術を搭載したシステムは，2003 年中ごろから実用され，多くの実績が上がっている.

以上述べたように, 本功績は, 建築鉄骨に打ける溶接工程の生産性向上・コス卜 低減に大いに寄与するとともに，学術的にもロボット溶接の特徴を生かした興味あ る開発であり, 今後の発展性も期待される. 


\section{略歴}

松 村 浩 史

1969 年 1 月 17 日生

1992 年 3 月 新潟大学 工学部 機械工学科 卒業

1992 年 4 月 (株神戸製鋼所 入社

2007 年 1 月 (株)神戸製鋼所 溶接カンパニー＼cjkstart溶接システム部 主任部員

現在に至る

定 廣 健 次

1965 年 9 月 28 日生

1988 年 3 月 長岡技術科学大学工学部機械システム工学課程卒業

1990 年 3 月 長岡技術科学大学大学院工学研究科機械システム工学専攻修了

1990 年 4 月 (株神戸製鋼所 入社

2004 年 1 月 株神戸製鋼所溶接カンパニー＼cjkstart溶接システム部主任部員

現在に至る

高田 篤 人

1974 年 3 月 31 日生

1996 年 3 月 電気通信大学電気通信部機械制御工学科卒業

1998 年 3 月 電気通信大学大学院電気通信学研究科機械制御工学専攻修士課程修了

1998 年 3 月 (株)神戸製鋼所入社

現在に至る

曽 賀 光 郎

1949 年 8 月 19 日生

1976 年 3 月 大阪大学大学院工学研究科機械工学専攻修士課程修了

1976 年 4 月 株式会社神戸製鋼所入社

1990 年 1 月 株式会社神戸製鋼所新分野事業部装置ロボット部主任部員

2004 年10月 株式会社神戸製鋼所退社

2004 年10月コベルコロボットサービス株式会社入社

現在に至る 
溶接学術振興賞は，平成元年 9 月に創設され，各支部において，溶接・接合に関し，学術研究及び教育活 動により学術・技術の振興, 進歩発展に著しく貢献した方に対し, 支部長の推萀に基づいて審查し, 学会長 から贈られます。

\section{北海道支部}

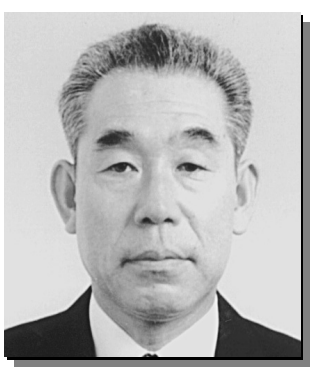

佐 藤 浩 一 君 昭和15年8月 9 日生 北海道大学名誉教授

佐藤浩一君は平成16年 3 月に北海道大学を停年により退官，同年 4 月に北海道 大学名誉教授の称号を授与された。退官後は，「第三者社会基盤技術評価支援機 構・北海道」の理事として現在活動中である. 同君は北海道大学に勤務して以来, 上記の 2 つの講座において 33 年間を教育・研究に携わってきたが, この間に橋梁 工学，鋼構造学，合成構造捛よび構造工学の分野において顕著な業績を挙げられ ているが，その中で多径間吊橋に関し未来の超長大吊橋の実現を示唆した研究抒 よび合成構造物の不完全さに関する研究等に優れた研究成果を示した．特に，溶 接・接合に関しては, 合成構造物のスタッドジベルの変形を考慮した研究におい ては我が国ばかりでなく, 国際的に通用する「佐藤の式」として先端的な研究を 展開し, この分野の進歩と発展に大きく貢献した。また，教育の面においても， 同君は, 北海道大学工学部土木工学科の学生に対して, 溶接法・機器, 設計 - 力 学に関する溶接工学を橋梁工学と鋼構造学の講義の中で開講している.

（社）溶接学会においては，評議員，北海道支部商議員幹事，北海道支部副支 部長，さらに平成 14 年から 1 期 2 年間北海道支部長を務めた。支部長時代に（社）溶接学会北海道支部学生 奖学賞を創設するとともに，北海道に打ける溶接技術に関する多くの講習会・講演会・見学会等の企画と実 施を（社）溶接協会の協力を得ながら中心となって推進するなど，溶接技術の振興に著しく貢献した.

また，関連分野として，北海道地区溶接技術検定委員会委員，北海道土木技術会鋼道路橋研究委員会委員 長，札棍市地震対策土木技術検討委員会委員長など，また，その他数多くの委員長を長期に亘り務めており， 鋼橋や鋼構造物の鋼材の接合に関する技能者技術の質の碓保と先端技術の開発に関わるとともに，土木学会 評議員，同北海道支部長，土木学会 2003 年十勝沖地震被害調查団団長などをはじめ土木学会における各種委 員会委員を歴任し，学協会の発展抢よび地域社会の産業基盤技術の育成と振興に著しく貢献した．現在は溶 接・接合の開発を含めて「耐侯性鋼材橋梁計画マニュアルに関する第三者評価支援委員会」の委員長を務め ている。

以上のように同君は，学術研究や教育活動を介して行われた溶接・接合技術の普及発展に対する貢献，な らびに溶接学会をはじめ, 溶接協会, 北海道地区溶接技術検定委員会, 土木学会等の関連学協会活動を通し て溶接・接合ならびに関連産業の学術振興に寄与した功績はまことに顕著である.

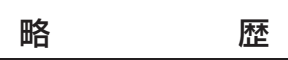

昭和 41 年 3 月 北海道大学工学部土木工学科 卒業

昭和 43 年 3 月 北海道大学大学院工学研究科土木工学専攻修士課程修了

昭和 46 年 3 月 北海道大学大学院工学研究科土木工学専攻博士課程修了

昭和46年 4 月 北海道大学工学部 助手に採用

昭和48年 4 月 北海道大学工学部 講師に昇任

昭和 49 年 4 月 北海道大学工学部 助教授に昇任

平成 5 年 4 月 北海道大学工学部 教授に昇任

平成 9 年 4 月 北海道大学大学院工学研究科 教授に配置換

平成16年 3 月＼cjkstart北海道大学を停年により退官＼cjkstart同年 4 月北海道大学名誉教授 


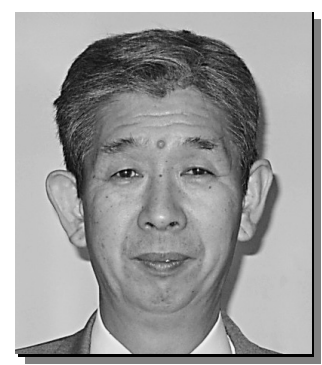

豊 原 力 君 昭和 21 年 2 月 18 日生 (株)MHIシーテック 技術部担当部長

豊原力君は, 昭和 44 年大阪大学工学部溶接工学科を卒業後, 三菱重工業(侏)に入 社，神戸造船所に配属．爾来，三十有余年に亘り，主に造船における，溶接技術 をはじめとする生産技術全般について, 学術的な研究開発に従事, 実用化の成果 を挙げてきた。平成13年 4 月には社内外での優れた業績を評価され，初代の「技 監」の一人に認定された．平成 18 年 3 月，同社を定年退職後は，これまでの蕰 蓄・経験を活かすべく, (株) MHI シーテックの嘱託として, 後輩の技術的・精神的 指導に当っている。

同君の学術的業績は, 概, 次の通り.

（1）我国初のコンテナ船「箱根丸」を始めとし，頓に大型化するコンテナ船の， 高張力鋼・厚板構造に対して, FCB 溶接法から 2 電極エレクトロガス溶接法 まで，各種大入熱溶接法の開発に取り組み，勒性劣化，強度低下を極小とす る施工条件を究明，実用化に繋げることによって，溶接品質の向上，生産性 の大幅な向上に貢献した.

(2) 潜水艦の耐圧殼材料として世界初となる「超高張力鋼」の開発に尽力し, $0.2 \%$ 耐力と溶接入熱量と関係，遅れ割れメカニズム等，現場工作上の問題点 を解明し，「ゆうしお型」潜水艦への実用化に貢献した。

また，潜水艦耐圧殼の溶接自動化の研究に取り組み，光センサーを利用した開先画像処理技術や，部分溶 け込みによる熱制御効果を利用した電子ビーム溶接技術を開発，これらを実用化することによって，溶接品 質の飛躍的向上に貢献した。

(3) 深海潜水調査船の分野においては,「超高張力鋼」の熱処理技術や，狭開先 TIG 溶接技術の開発に取り組 み，「しんかい2000」の完成に貢献するとともに，「しんかい6500」でも，我国最大板厚となる.

$6 \mathrm{Al}-4 \mathrm{~V}$ チタン合金の電子ビーム溶接技術や，三次元機械加工技術を開発するなどして，その完成に貢献し た.

これらの成果により，溶接学会「田中亀久人賞」（2 回），同「溶接技術奨励賞」，同「溶接プロセス技術賞」 「日本造船学会賞」「防衛装備協会賞」等を受賞. 国内はもとより IIW 等，海外でも高い評価を得ている.

さらに同君は，溶接学会関西支部事務局を始め，溶接学会・日本溶接協会の各種活動においても指導的な 役割を果たすなど，我国溶接界の発展に大きく寄与してきた.

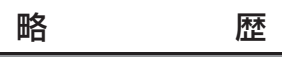

昭和 44 年 3 月 大阪大学 工学部 溶接工学科卒業

昭和 44 年 4 月 三菱重工業(株) 神戸造船所 入社

平成13年 4 月 三菱重工業(侏) 神戸造船所 造船工作部 技監・主幹プロジェクト統括

平成18年 3 月 (株) MHI シーテック技術部担当部長

現在に至る 


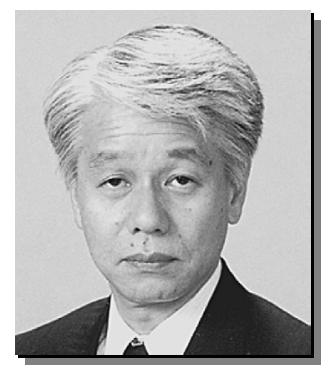

西尾一政 君 昭和 23 年 4 月 18 日生 九州工業大学大学院 生命体工学研究科教授
西尾一政君は昭和 49 年九州工業大学 - 大学院工学研究科 - 金属加工学専攻修士 課程を修了し, 同年に九州工業大学・工学部（金属工学科）に助手として採用さ れた. その後, 平成元年 4 月に助教授に昇任, 平成13年 4 月に大学院生命体工学 研究科教授に昇任, 現在に至っている. この間, 溶接材料学の研究及び教育活動 を行ってきた。

同君は, 軟鋼の溶接熱影響部のミクロ組織と切欠勒性に及ぼす $\mathrm{Ti}, \mathrm{Nb}$ 及び $\mathrm{Zr}$ の影響について研究し, 組織と切欠勒性との関係並びにこれらの特性に及ぼす Ti と $\mathrm{N}$ の含有量の関係性について明らかにした。また，難溶接材料である球状黒鉛 鋳鉄の接合に拡散接合法を適用し，その接合部の組織と機械的特性について明ら かにすると共に, この接合法を応用して, 数層の球状黒鉛鋳鉄と軟鋼から成るク ラッド材を圧延することにより制振性複合材料の開発も行った。さらに，アルミ ニウム青銅とステンレス鋼との拡散接合が難しい原因を突き止め，被接合面の酸 化皮膜を破壞しながら接合することが可能な真空圧延接合法を開発した。本接合 法により通常の拡散接合では接合部に金属間化合物を形成する組合せの $\mathrm{Al} /$ 鋼及び $\mathrm{Al} / \mathrm{Ti}$ などにおいて，金属間化合物を形成させない接合法を実現した。これらの接合部には，アモルファスま たはナノ結晶帯が形成していることを TEM 観察により明らかにした.このように溶接・接合の分野において 大きな成果を挙げ，溶接学術の発展に貢献したところ大である.

また, 同君は溶接学会溶接治金研究委員会幹事, 九州支部商議員・幹事を歴任し, 学会の運営にも貢献す ると共に, 日本溶接協会九州地区検定委員会委員長として, 地域における溶接技術の普及, 啓蒙に努め, 溶 接技術の振興にも大きく貢献した.

以上のように，西尾一政君は溶接・接合に関する学術及び教育そして溶接技術の地域振興に寄与した功績 は誠に顕著である。 


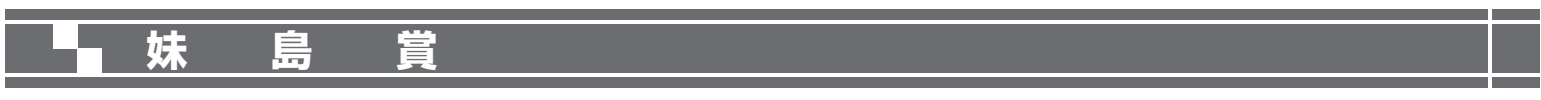

\section{造船用各種溶接プロセス自動化設備の開発および 造船所の近代化へ向けた知的生産システムの研究開発}

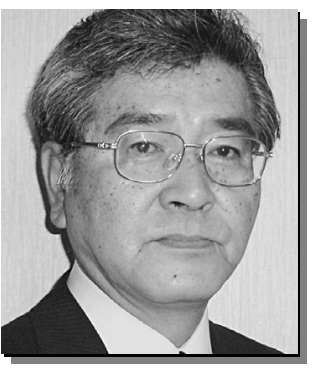

宮崎建雄君は昭和 47 年 3 月，九州工業大学工学部金属工学科を卒業後，直ちに日 立造船に入社し，同社の因島工場技監部において 2 年間勤務の後，昭和 49 年 4 月か ら同社の新鋭大型造船所有明工場に赴任し，そこにあって現在に至るまで一貫して 造船における生産技術の進歩・発展に貢献し，著しい功績をあげている.

まず，赴任当初は有明工場が操業開始直後の時期であり，同工場の技監部の技師 として各種高能率自動溶接法の開発・実用化に取組み, 大型船連続建造時代の自動 溶接技術を確立した．昭和50年代前半には，同工場が「船」，「陸」に継ぐ第三の柱 製品として多数建造した種々の「海洋構造物」の建造に抢ける高グレードな溶接施 工技術の確立に取組み，特に TMCP 鋼の海洋構造物及び船舶への利用を業界内にお いて先駆的に提唱し，これの溶接工作上の諸条件の解明を図ると共に，その積極的 な適用の拡大を推進した。昭和50年代後半には，我が国の造船所は低成長時代に入り，設備要員削減の重圧 の中で生産性の向上に即効性のある半自動炭酸ガスアーク溶接法の適用拡大に全国的規模で取組んだが，同 氏は本溶接法を造船に普及せしめる不可欠の手段として, 全姿勢用細径フラックス入りワイヤの開発・利用 を提唱し，これの改良・普及を計りながら，将来のロボットへの利用を念頭において，とりわけ自動溶接へ の適用特性に優れたフラックス入りワイヤの造船への普及を推進した。更に昭和60年代から最近にかけては 造船用各種溶接ロボットシステムの計画, 開発を積極的に推進し, これらロボットの造船における広範囲な 実用化に成功した。昭和50年代後半から今日に至るまで，氏が一貫した確信のもとに取り組んできた「造船 所の近代化へ向けた知的生産システム」の開発研究成果を, 学問体系の構築という観点から企業を離れ大学 に身を置き分析し直すために，氏は，九州大学大学院工学研究科博士後期課程に入学し，平成 8 年 9 月に, 造船学の博士 (工学) を授与された. 現在は, ユニバーサル造船株技術研究所の生産技術担当部長として, 同社姉妹事業所の生産技術変革を指導しながら若手技術者の育成に尽力している.

ここに，氏の最近の主なる業績をあげると，次のとおりである。

(1) 高速 $\mathrm{FCuB}$ 片面溶接法の開発,

(2) 造船用各種溶接ロボットシステムの開発,

(3) 造船所の近代化へ向けた知的生産システムの研究,

(4) 高性能 NC 印字装置の開発.

以上のと㧍り，氏の研究開発が我が国の造船工業界並びに溶接産業界など関連工業界における生産技術の 向上，進歩に寄与した功績はまことに顕著なものがある.

昭和 24 年 5 月 21 日生

昭和47年 3 月 31 日 九州工業大学工学部金属工学科 卒業

昭和 47 年 4 月 1 日 日立造船侏入社, 因島工場 技監部

昭和49年 3 月 16 日 同社 有明工場 技監部

平成 2 年 7 月 1 日 同社 有明工場 造船部 主管技師（溶接技術）

平成 3 年 4 月 1 日 同社 有明工場 システム開発部 生産技術開発課長

平成 6 年 6 月 29 日 同社 有明工場 生産技術開発室長

平成 8 年 9 月 30 日 九州大学大学院工学研究科 博士後期課程修了工学博士（造船学）

平成11年 4 月 1 日 同社有明工場生産技術開発室長 兼本社 技術企画部生産技術グループ長

平成11年10月 1 日 同社 船舶防衛事業本部技術統括部（生産技術）兼 有明工場 生産技術開発 室長

平成13年 1 月 1 日 同社 有明工場 生産技術開発部長 兼 船舶防衛事業本部 技術統括部（生産 技術)

平成14年10月 1 日 ユニバーサル造船侏 技術研究所生産技術センター長

平成18年10月 1 日 同社 技術研究所生産技術担当部長

現在に至る 
溶接学会ベストオーサー賞は，平成15年に創設され，会誌「溶接学会誌」に発表された記事のうち，特に 多数の会員の研鑽，及び，学術，技術の向上，普及に貢献した記事の著者に授与されます.

(1) 山根國秀君 日鐵住金溶接工業(侏)

第75巻 7 号 材料企画担当記事「低ヒューム溶接材料について」

アーク溶接過程で生じるヒューム問題を取り上げ，その発生機構，化学成分，さらにはヒューム発生量 に扔ける組成・溶接条件の影響などを，ソリッドワイヤ，スラックス入りワイヤ，被覆アーク溶接棒など に関してわかりやすく説明しており，かつ，低ヒューム対策溶材やヒューム除去方法についての説明もさ れている．昨今，環境問題に対する関心は高まるばかりであり，溶接作業者の健康管理に直結するこの問 題をわかりやすく解説している本記事は, ベストオーサー賞に值すると判断した.

(2) 南 二三吉君 大阪大学

第75巻 5 号 レビュー\&トレンド「ワイブル応力を用いた破壊評価手法」

本記事は，その扱っている内容の広さおよび詳しさを考虑すると, 破壊力学の教科書と言える内容を含 んでいる，実験デー夕，解析結果などが詳しく紹介され，また，後半には，WES 2808 の詳しい説明もあ り，この分野の専門家のみならず，溶接学会会員にとってきわめて有用な内容と判断できる.よって，本 記事はベストオーサー賞として推薦するにふさわしいと判断される.

(3) 内田雅信君, 辻井 元君, 大縄登史男君 ダイヘン(株)

第75巻 2 号 実用講座「防錆溶射技術の現場適用」

会員に比較的なじみが薄いアーク溶射について，原理，防錆メカニズムを分かりやすく説明し，多岐に わたる適用事例を解説. 
溶接技術奨励賞は，昭和63年10月に創設され，各支部において溶接・接合に関し，研究・開発・改良ある いはその実用化の功績顕著な方にその地域の支部長から贈られます。

\section{北海道支部}

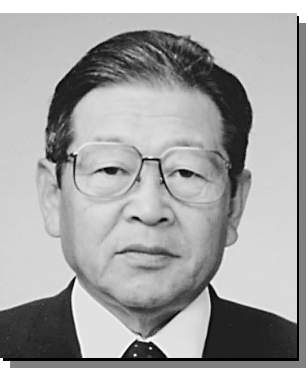

阿部仁氏 昭和13年4月13日生 阿部鋼材(株)

阿部仁氏は, 昭和 37 年 4 月阿部鋼材(株に入社後, 鋼製水路・防雪柵・防風柵や 鋼製高欄の製作工程に従事して溶接の技能を学んだ後，油圧プレス及びベンティ ングローラー加工部材等の溶接歪を最小限にする研究を行い, 溶接歪除去のプレ スや焼鉄作業時間の削減に成功した。また，防雪柵・防風柵等の小口径鋼管部材 の溶接作業においての安全作業，溶接品質向上の為にターニングローラーの開発 を行った。

平成 3 年に日本溶接協会北海道札幌支部理事に就任後，会員企業内で実際に溶 接に携わっている技能者や検査員が事前に公表したテーマに関して，日頃感じた 問題点や疑問点をお互いに企業の壁を乗り越えて食事をしながら話し合う中で改 善・解決策を導き出す実務者懇談会を積極的に支援した.

平成 9 年 7 月に札幌支部長に就任してからは，日本溶接協会主催の全国溶接技 術競技会の札幌地区（石狩，空知，後志支庁管内）予選である札幌支部溶接技術 競技会に参加する企業及び選手が毎年減少傾向であったのを打開するために，競 技会参加選手募集ポスターを前年度の競技会参加選手と競技役員の集合写真と次年度の JIS 検定試験日を取り 入れたカレンダー形式にしたことで会員企業や溶接技能者の高評を得て参加企業や選手も増加し，札幌支部 からの参加選手の技量は，全国溶接技術競技会で最優秀賞を獲得する 1 歩手前まで達している．参加選手全 体の技量レベルが上がってきたのは，全国溶接技術競技会で最優秀賞に輝いた選手に阿部支部長が豪華な副 賞で進呈することを溶接技術競技会の開会式や表彰式で参加選手に公言していることが影響しているのかも しれない.

阿部仁氏の溶接業界活動は，平成 9 年 7 月から日本溶接協会北海道地区支部委員会委員長に，平成 12 年 6 月にガス溶接技能講習教育機関の北海道溶接協会会長に，平成15年 4 月から日本溶接協会全国地区支部委員 会副委員長に就任されている.

\section{東北支部}

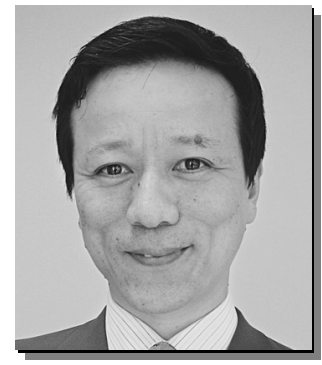

来 次 浩 之 氏 昭和37年6月18日生 山形県立産業技術短期大学 校メカトロニクス科 助教授
来次浩之氏は昭和 62 年 3 月山形大学大学院機械工学専攻修士課程を修了後，山 形高等技術専門校機械科指導員を経て，平成 5 年 4 月より山形県立産業技術短期 大学校に勤務し, 平成 12 年 3 月には, 山形大学大学院理工学研究科物質生産工学 専攻博士後期過程を修了し，工学博士を取得した。

平成10年から 7 年間大阪大学接合科学研究所の共同研究員としてアルミナ溶射 材料の腐食瘏労特性の解明と溶射皮膜密着力評価に関する研究に取り組み, 平成 12年度には“アルミナ溶射被覆 SUS316L ステンレス鋼の生理食塩水中における腐 食疲労挙動”で高温学会論文賞を受賞し，金属材料の表面改質分野での積 極的な 調査・研究ならびに学生指導を続けている.

溶射材料の機械的特性や接合強度については，異業種交流会などでの発表や技 術支援を行うなど地元企業への表面改質技術の普及にも寄与している.

また，日本溶接協会東北地区溶接技術検定委員会評価員および山形県溶接技術 競技会審査委員として，東北地域における溶接技術の発展および振興に長年にわ たり貢献している.

以上のように，来次浩之氏の溶接技術の開発・実用化に寄与した功績は誠に顕 著である。 


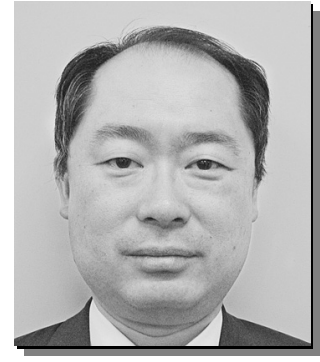

佐々木 正 司 氏 昭和38年7月29日生 青森県工業総合研究センタ 一八戸地域技術研究所機械 システム研究部 主任研究員

佐々木正司氏は 1986 年東北大学工学部資源工学科を卒業，1988 年同大学院博士 前期 2 年の課程を修了した後，ただちに新日本製鐵株式会社に入社し，高強度ワ イヤの開発等，鉄鋼線材の高機能化に関する研究開発に携わった. 1999 年に退社 し，ただちに当時の青森県機械金属技術研究所（現在の青森県工業総合研究セン ター八戸地域技術研究所）に採用され，現在に至っている.

同氏の業績は，青森県内企業ニーズを対象としたレーザ接合研究に代表される. 特に，はんだの代替として開発した金属細線と金属細線束のレーザ接合技術は世 界でも報告例がなく，この技術は 2006 年に青森県内の企業において，サーミス夕 温度センサ端子線と銅リード線の製造工程に組み込まれ実用化された。具体的に は，金属細線束の各素線を密着させ均一溶融させるための簡易的方法の提示，細 線束の均一溶融条件とメカニズム解析, 溶融から溶断までの熱 伝達機構の解析, 実用的な高確率レーザ接合技術の確立を行った。特に，細線束先端部にレーザ照 射した場合に，照射方向に溶融部が偏る特徵があることを見いだし，これを応用 して，偏った細線束溶融部に細線を接触させることにより接合が $100 \%$ 成功する こと，その実用的評価においても従来品と同等であることを明らかにした。さら に実用化する際に問題となるレーザ照射位置の範囲を $0.01 \mathrm{~mm}$ のオーダで制御す ることにより完全な接合が可能であることを明らかにした。この知見を利用して企業が自動化技術を完成さ せ実用化に至った，RoHS に代表される有害物質規制の進む中，環境に優しく，現状工程の省略，生産性の向 上, 消耗品コストの削減といった効果がある画期的な代替え手段として, 今後の用途拡大も期待されている. この成果を主としたレーザ接合研究について室蘭工業大学から 2005 年 3 月に博士（工学）の学位を授与され た。

同氏はこれまで，地元企業からの技術相談や他の分野の研究もこなしながら，溶接学会論文集へ投稿（3 編)，特許出願（ 4 件）などを積極的に行い，また，溶接学会全国大会，公設試験研究機関の発表会および溶 接接合研究会などにおいても数多くの成果を発表するなど活躍が著しい.さらに最近では，箔などの極薄板 についてレーザ接合のみならず超音波接合も取り入れ，研究の幅を拡大している.

以上のように，同氏の溶接・接合技術の発展に寄与した功績は顕著である.

\section{東部支部}

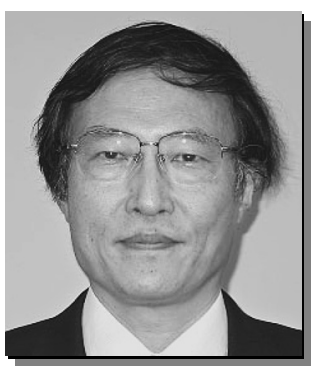

村 松 由 樹 氏 昭和19年12月2日生 元 (独) 物質・材料研究機構

村松由樹氏は，昭和45年 3 月大阪大学大学院修士課程修了後，科学技術庁金属 材料技術研究所（現（独）物質・材料研究機構）に入所し，以来一貫して溶接部 の熱伝導，各種割れならびにひずみ測定に関する研究を行い，主として溶接学会 で活発に研究発表・論文発表を行ってきた.

中でも平成元年より開始したレーザースペックル法による溶接部のひずみ測定 に関する研究は，それまで困難であった溶接施工途上のひずみの in-situ 測定を可 能とし，数值計算等による実証もなされており，高く評価されている．これに付 随して, 本測定の応用として溶接部の相変態挙動の検出, 溶射皮膜の剥離性の判 定等に関する論文発表も行っている．特に溶接部の相変態については，それまで 小型の再現試験で推測していたものを実施工において検出したものであり，(独） 物質・材料研究機構で平成 17 年度まで行われた超鉄鋼開発の一環として低变態温 度溶接材料を用いた溶接施工途上の変態挙動の確認に大きな成果を上げた.

一方，昭和50年以前より溶接学会溶接構造研究委員会委員（のち幹事）として 溶接力学の研究発展にも努めている.

以上のように，村松由樹氏は永年にわたる溶接技術の研究・開発・向上に果たした功績はきわめて顕著で あり，高く評価される. 


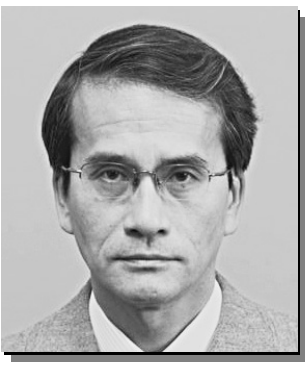

榎 本 清 志 氏 昭和 25 年 9 月 24 日生 （財）次世代金属·複合材料 研究開協会複合材料技術部

榎本清志氏は昭和 48 年東北大学金属加工学科を卒業後, 三菱重工業(株に入社し, 主に以下に示す種々の接合技術の実用化推進にマネージャとして多大な寄与をし， それらの技術開発を通して日本を代表する輸送機器の開発を成功に導いた.

1）液体ロケットエンジン（LE-7 等）の接合技術の確立とその信頼性向上

日本の中心的なロケットである H-II ロケット・シリーズの第 1 段エンジンであ る LE-7 エンジン（推力約95トン）に使用されているニッケル基超合金等の溶融溶 接/ろう付けに関して，その接合技術の確立と信頼性向上のための研究開発を積極 的に推進し，H-II ロケット用 LE-7 エンジンの開発を成功に導いた.

2) 宇宙ステーション日本モジュール「希望」の溶接組立

宇宙ステーションに結合される日本のモジュール「希望」のアルミニウム合金 構造組立において, H-II ロケット・タンクの溶融溶接技術を応用して, 気密性に 優れた「希望」の圧力部分の溶接組立を推進した.

3) 高速車両の摩擦擋拌接合 (FSW) 技術の開発

リニアモーターカーの先頭車両を航空機構造と同じセミモノコック様式で組み 立てる場合，リベット組立に代わり摩擦擋拌接合を適用するための技術開発を積 極的に推進し，試作車を完成させて実験線走行を実現した。現在，このFSW 接合 技術は，新幹線の新型車両製造に広く適用されている.

また，平成14年度全国大会実行委員会副委員長，東海支部商議員，幹事，支部長および監事を10年に亘り歴 任し，全国大会開催および支部活動に尽力した。

以上のように，同氏の接合技術の開発および支部活動を通した接合技術の普及・発展に貢献した功績は顕 著である。

\section{関西支部}

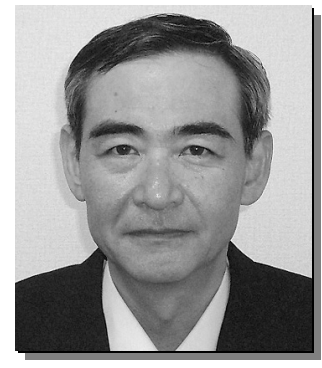

笠 谷 龍 也 氏 昭和31年10月29日生 住友金属パイプエンジ株) 技術本部施工技術部施工技 術室長
笠谷龍也氏は，昭和 54 年 3 月，大阪大学工学部溶接工学科を卒業後，同年 4 月住 友金属パイプエンジ株に入社，現在に至るまでの 27 年間に亘り溶接の能率・品質 向上のために MAG 溶接, TIG 溶接のセンシング及び自動化技術を開発し, 都市ガ ス導管, プラント配管への適用を精力的に進めてきた.

この分野における先端的な自動化，知能化技術の開発と実用化に果たした業績 は顕著であり，溶接技術奨励賞を受賞するにふさわしいものとして推薦いたしま す.

同君の主な業務をあげると次の通りである.

（1）全姿勢，全自動 MAG/TIG 溶接装置をいち早く開発し，都市ガス高圧幹線工 事，プラント配管への適用を進めて，パイプライン建設期間短縮と，信頼性 向上に貢献した.

（2）インプロセスセンシング並びに溶接条件の適応制御技術を，MAG 溶接と組み 合わせたロボットを開発し, 都市ガス高圧幹線工事へ適用し, 溶接品質, 効 率向上に貢献した。 


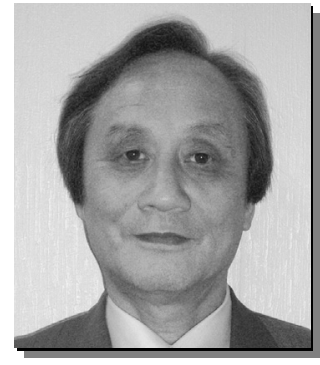

三田村 智 三 氏

昭和 21 年 6 月 2 日生 新明和工業(侏航空機事業部 甲南工場生産技術部
• 1971 年 大阪大学工学部溶接工学科卒

- 同年 新明和工業(株入社

- 熱機関協会（原子力発電機器）の通産大臣資認定や鉄骨構造物の大臣認可取得 に尽力.

・社内各工場からの溶接に関する施工方法や事故対応に対するアドバイスを行う.

- 社内溶接構造物技術者認定制度の実行段階（1993 年）より，その講習会の講師 を勤め, さらにその実行計画から試験問題の作成，採点，認定手続きまでを行 う.

・ 2005 年度まで社内技能競技会の被覆アーク溶接，半自動溶接，ティグ溶接，ロ ボット溶接の種目委員長を勤める。

・技術推進委員会の事務局として社内の技術全般の推進に勤め，溶接・製缶部会 では副部会長を務める。

・溶接学会 1971 年から正会員（代議員経験あり）

・溶接学会関西支部 幹事 (2003 2005 年度)

・溶接協会兵庫県支部会員（2005 年度まで）

・軽金属溶接構造協会会報に 2 度投稿

- WES 溶接管理技術者特別級（2000 年度）取得

・ IIW-IWE 資格習得 (2001 年度)

すでに資格はなくなったが普通・特別ボイラ溶接士の資格を取得していた。

\section{中国支部}

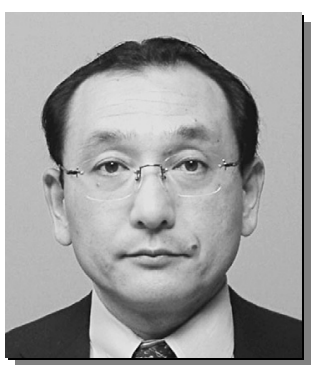

遠 藤 茂 氏 昭和35年5月30日生 JFEスチールスチール研究 所主任研究員

遠藤茂氏は，昭和60年 3 月京都大学大学院工学研究科金属加工専攻を修了後, 日本鋼管株式会社（現 JFE スチール）に入社．以降，一貫して技術開発部門に在 籍し，高性能溶接構造用鋼，特に，パイプラインやプラント配管などに用いられ る各種高性能溶接鋼管の開発と実用化に従事してきた.

これらの成果を学術論文（論文リスト添付）としてまとめ，1999年には大阪大 学大学院工学研究科から工学博士の学位を授与されている. 学術論文の執筆に加 えて, 国内外の工業所有権を得るべく，100 余件の特許出願を行ない，この内30件 は既に日本国特許として登録されている。

その主な実績を挙げると次の通りである.

1. 天然ガス輸送に用いられる長距離パイプライン用の超高圧ラインパイプの開発

2. 大変形パイプライン用高変形性ラインパイプの開発

3. 高機能高強度鋼管（耐磨耗性鋼管，耐食性鋼管）の開発

4. 高強度海洋構造物用の開発

これらの成果はラインパイプ・プラント配管の製造，あるいは高圧パイプライン 溶接敷設の分野で大きな影響を及ぼし，業界全体の技術向上の一翼を担った.

また，平成10年度より（社）溶接学会中国支部商議員（幹事）として，中国地区の溶接技術の発展点普及 に大いに貢献している。さらに，平成7年には（社）日本鉄鋼協会鋼管部会 HLP 技術検討会委員として「鉄 鋼協会山岡賞」を，平成14年には「オンライン加速冷却技術の開発」で財団法人岩谷直治記念財団から「記 念賞」を受賞している.

以上のように遠藤茂氏の永年にわたる溶接技術および溶接構造物の研究，開発ならびに実用化に果した功 績は誠に顕著である。 


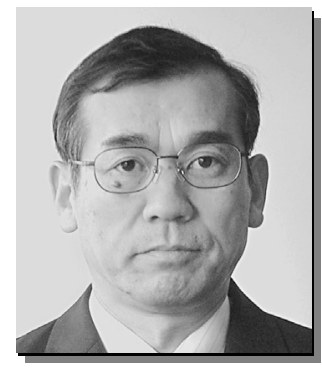

中 島 一 夫 氏 昭和 24 年 8 月 18 日生 三菱重工株社長崎造船所役 職主任

中島一夫氏は入社以来 42 年間に亘り主に船舶の船体溶接関係業務に従事してき た.この間, 時代の変遷に伴って要求される新技術の導入, 品質向上及び生産性 向上などに対し，長年の現場作業の経験や独自のアイデアを生かし，常に積極的 に取り組み多大なる成果を上げてきた。

船体溶接一筋で得た豊富な経験とノウハウを生かし, 一般商船から客船, LNG 船, LPG 船, アルミ製高速物流船に及ぶ幅広い船種において, 工法改善と技術伝 承に取り組んできた。

特に船体部の溶接工事における新溶接法の開発・溶接の自動化, 機械化, 装置 化などを積極的に実行し, 造船の溶接技術の革新に数多くの功績を残した. 中で も高品質が要求される LNG 船, LPG 船においては, 溶接施工法の確立に中心的役 割を果たしたことは高く評価されている.

また，女神大橋等の橋梁の溶接施工計画，溶接技術管理業務にも従事しており， 幅広い溶接技術の経験を有している．職場では，後進の指導育成に関しても責任 者的存在であり，公私に亘り，愛情と誠実さを持って多くの技術者を育成してき た。平成10年からは日本溶接協会長崎県支部の溶接技術競技会審査委員として活動しており，社外において も溶接技術の振興, 普及, 溶接士の育成に貢献してきた.

以上のとおり，同氏は技術的分野ならびに人材の育成を通じて溶接業界へ貢献すること大である.

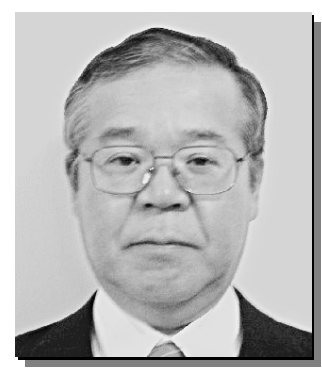

山田誠 氏 昭和 25 年1月 17 日生 (株)名村造船所伊万里事業所 生産技術開発部部長

山田誠氏は九州大学工学部を卒業後, (株名村造船所に入社以来33年に亘り, 主 に船舶の溶接関係の業務に従事してきた。

昭和55年に生産管理部に配属となり, 船体中央部組み立てラインへの水平すみ 肉溶接升目ロボットの開発・導入に成功した。昭和 62 年以降は, 同社の工場全体 の溶接技術の取りまとめ業務に従事しており，この間アルミ合金製高速艇の片面 自動溶接装置の製作, 船体中央部のパネルラインへの $\mathrm{CO}_{2}$ 簡易自動溶接装置の大 量導入による溶接コストの削減, 低温用アルミキルド鋼板の片面高能率サブマー ジ溶接法の指導・実用化, 降伏点 36 キロ鋼 Gr. Eへの大入熱エレクトロガスアーク 溶接の実用化および $3 \% \mathrm{Ni}$ 鋼の溶接施工法の確立と社内教育, 実用化等数々の業 績を上げてきた。

また，設計部門において圧力容器の見積もり，設計およびASME スタンプ取得 業務にも従事しており, 工作部門の技術のみならず溶接に関して幅広い経験と知 識を持っている.

これらの業績，経験を基に，平成 4 年 9 月にIIW・MARIDID にて“Simple Mechanized Welding for Shipbuilding in Japan"State of the Arts -を発表, 平成13年 5 月には溶接学会・溶接法研究委員会と日本溶接協会・船舶海洋鉄構構造物部会の交流会で「造船業界の現 状」を講演している。

平成15年から18年度にかけ, 溶接学会九州支部主催の「溶接設計講座」で溶接施工管理の講師を担当して おり，溶接技術者の教育指導，育成にも貢献してきた。平成16年からは溶接学会九州支部商議員を務めてお り，社内外で溶接技術の発展に貢献してきた.

以上のとおり，同氏は技術的分野ならびに人材の育成を通じて溶接技術の振興へ貢献すること大である. 
溶接技術普及賞は平成 2 年11月に創設され，各支部において，溶接・接合に関し，講座・講習会の講師， 見学会, 展示会の企画・実施等により, 技術・技能の普及, 発展に著しく貢献した方にその地域の支部長か ら贈られます。

\section{北海道支部}

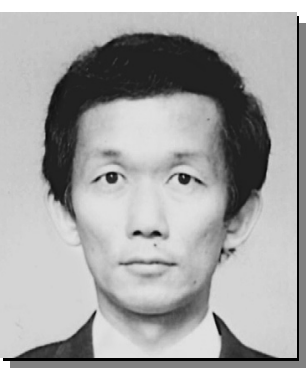

田 中 之氏 昭和34年5月3日生 北海道立工業試験場 材料技術部金属材料科科長
田中大之氏は, 昭和 59 年に北海道大学大学院工学研究科金属工学専攻修士課程 を修了後, (株)日立製作所生産技術研究所に勤務し, はんだ付けやろう付けを中心 とした半導体パッケージの実装技術の開発に従事した。平成 3 年 10 月に北海道立 工業試験場に勤務してからは，レーザーを用いた表面改質技術，超音波評価技術， 鉛フリーはんだを用いた電子部品実装技術に関する試験研究及び技術指導を通じ て，道内外関連企業への技術支援及び技術向上に尽力してきた。

平成10年から（社）溶接学会北海道支部幹事として，支部行事のセミナー，講 習会等の企画，運営に携わってきた.

平成14年から平成15年まで（社）溶接学会評議員に従事した.

平成13年から平成16年まで IMS 国際共同研究開発プロジェクト「環境対応次世 代接合技術」に参画し，鉛フリーはんだの研究開発に従事して得られた成果を道 内の電子部品関連企業に普及してきた.

\section{東北支部}

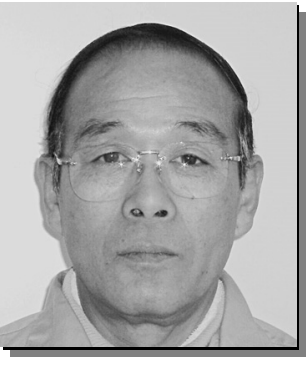

市 荘 三 氏 昭和 22 年 6 月 12 日生 東北建機工業(株)主任特級
種市荘三氏は昭和39年東北建機工業(株に入社以来，42年間にわたり金属製品製 造一筋でものづくりに情熱を燃やし，特に溶接においては優秀な技能を持ち，県 大会で最優秀賞，全国大会でも優良賞を得るなどの実績がある。アーク溶接，半 自動溶接，TIG 溶接に高い技能を有し，鋼構造物，配管，製缶，ボイラー類等の 溶接を担当し, 官庁検査の合格率は非常に高い。溶接業務に限らず，昭和56年に はむつ小川原石油備蓄基地, 平成元年には六ヶ所原子燃料サイクル施設関連の各 種鋼構造物の製作に携わり，平成 2 年には特に難度の高い展開現寸作業を伴う六 ヶ所原燃 PR センター屋根構造物などの溶接工事を完成させるなど，業界でも極め て優れた実績を残している.

後進の育成にも情熱を注ぎ，社内で溶接指導した社員が全国大会優良賞を獲得 するなど輝かしい実績を有する．現在は製造部の主任特級として製造業務を担当 しながら部下の指導育成を行っている.

社外においても，積極的に溶接技術の発展に貢献しており，青森県，八戸市等 からその功績が認められ表彰されている．H11 年の東北六県溶接技術競技大会で は実行委員を務め，会場設営や監視役員として職務を立派に全うした。さらに，下記のとおり，多くの職種 の候補がいるにもかかわらず溶接業務の功績が認められ，八戸市卓越技能者，あおもりマイスター，高度熟 練技能者に認定されている．忙しい業務の中にもかかわらず，青森県内の高校，専門学校，企業等に溶接指 導に出向き，溶接技術の普及に貢献してもらっている.

以上のように，種市荘三氏の長年にわたる社内および社外の溶接技術の普及・発展に寄与した功績は顕著 である。 


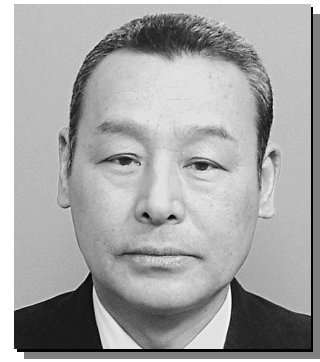

松本昭司氏 昭和 19 年 3 月 2 日生 雇用・能力開発機構山形七 ンター（山形職業能力開発 促進センター）金属加工科 講師

松本昭司氏は, 昭和 37 年 3 月山形県立村山農業高等学校農業科を卒業し, 直ち に東京芝浦電気株式会社に入社した後, 山形総合高等職業訓練所溶接科へ 委託訓 練生として 6 カ月間入所し, 溶接の基礎を学んだ.その後, 東京芝浦電気事業所 内の訓練施設にて溶接技能訓練を受け，入社 1 年後より約 6 年間にわたり溶接作 業員として蒸気タービン製造に携わった。 その間, ケーシング, 給水加熱器, 蒸 気管, 給水管等の溶接作業, 火力発電所, 原子力発電所等の蒸気 タービン据え付 けに伴う現場溶接施工の作業に従事し技術の研鑽を積んだ。昭和 45 年 4 月からは 地元に戻り, 企業での豊かな経験を生かし, 新庄総合高等職業訓練校溶接科に勤 務し, 溶接技能者の育成に努めた。訓練生の JIS 溶接資格取得に向けた取り組みで は，常に高い合格率を保持するとともに優秀な修了生を県内外に送り出し，産業 界の発展に多大な貢献した。 また, 当時は溶接検定試験が新庄地区では行われて おらず，新庄地区でも新庄総合高等職業訓練校の施設を会場に試験ができないか と思い, 日々日本溶接協会山形県支部へ陳情し, 支部の特別の配慮でようやく臨 時の試験開催まで漕ぎ着いた。このことは, 同氏の溶接に取り組む熱意の表れで あり，技術の普及に対するその姿勢は高く評価される。ささに，当初は年 1 回訓 練生のみの試験実施だったが，一般の方にも技術の浸透を図った結果，現在では年 2 回開催されるまでにな り，広く溶接技術の啓蒙・普及にも尽力した.

新庄勤務中は在職者向けガス溶接技能講習, アーク溶接等特別教育講習の講師, 昭和 62 年山形技能開発セ ンター金属加工科へ勤務してからは, 前出の 2 講師の他に溶接関係の離職者訓練, 在職者向け能力開発セミ ナーの講師，技能検定試験（構造物鉄工，建設機械整備等）の検定委員も担当し，幅広く業界発展のため貢 献した。

また，日本溶接協会山形県支部主催の溶接コンクールでは審査員として活躍する一方，平成 5 年からは日 本溶接協会の溶接検定試験立会員として 4 年間厳正な審査を担当した.そして，平成16年度からは，嘱託講 師として山形職業能力開発促進センター内で溶接関係の指導・教育育成業務を担当し, 技術者の育成に邁進 している.

以上のように，同氏の長年にわたる溶接・接合技術の普及・啓蒙に貢献した功績は誠に顕著である.

\section{東部支部}

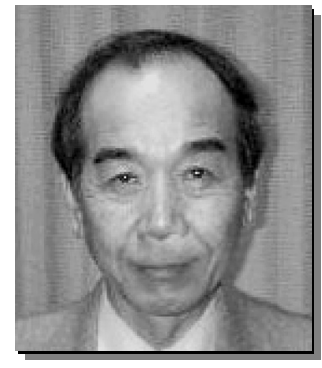

塩 浦 時 宗 氏 昭和25年7月 19 日生 （財）新潟県県央地域地場 産業振興センター産業開発 部部長
塩浦時宗氏は, 平成 4 年10月の東部支部新潟地区溶接技術講習会「地場産業と 溶接」の開催への協力以来，現在まで14年間にわたり，東部支部新潟地区溶接技 術講習会の開催に積極的に協力され，「チタン薄板の接合技術」，「接着技術の基礎 と応用」,「マグネシウムの溶接技術」など地域の特色に配慮したテーマを設定し, 新潟地区の溶接技術の普及に多大なる貢献をされている.

また，同氏は，(財)新潟県県央地域地場産業振興センター内に, 平成12年度より 産学協同開発事業として「接合技術研究会」を立ち上げ，単に勉強会ではなく， 会員に課題を出し, 溶接作品を持ち寄り, 溶接技術について議論するなどの方法 により，地域の溶接技術者の溶接技術の確実な普及ならびにレベルアップに力を 注ぎ，この地域でのチタン溶接技術，ならびにマグネシウム合金の溶接技術の導 入に主導的役割を果たし，地場産業の活性化にも重要な貢献をされている. 


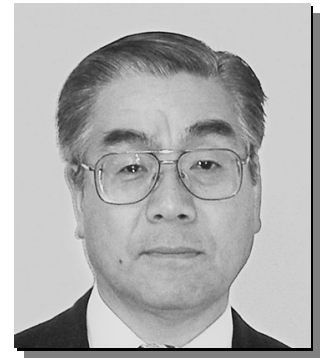

六本木覚氏 昭和27年2月7日生 富士重工業株式会社 群馬製作所 総務部人事課 職業訓練校講師

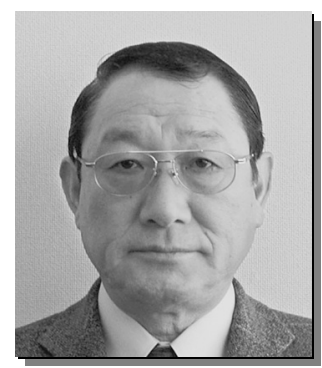

渡 戸昌幸 氏 昭和 22 年 12 月 16 日生 石川島検查計測(株) 研究開発事業部生産技術部 課長
六本木覚氏は，昭和43年に富士重工業株式会社群馬製作所に入社以来，試作車 両の単一部品加工をかわきりに，車体集成および技術開発を担当し，試作部門の 技術技能の発展に貢献し, 更には職業訓練校専任講師として, 所内の溶接技能の 普及指導に大きく寄与した.

同氏の溶接技能の普及に関する主な業績を挙げると以下のとおりである.

（1）アセチレンガス溶接，被覆アーク溶接，炭酸ガスアーク溶接などの車体集 成に欠かせない溶接専門知識と, 技能の普及に職業訓練校をとおし人材の 育成指導に励む。

（2）車体集成における溶接技能の基礎を，基本どおりに体得できるまで徹底し た指導を行い，氏の溶接品質良否判断を基に更なる技能指導を行う.

(3) 群馬県東部地区における溶接技能特別講習講師として，地区内あらゆる業 種の技能者指導にも携わる.

渡戸昌幸氏は，昭和45年に石川島播磨重工業(株に入社以来，溶接技術に関連す る研究開発に従事し, 溶接自動化技術の発展に貢献してきた。 また, 平成 13 年に 現職に移った後は, これまでの経験を活かし若手研究者, 溶接工の指導・育成に 意欲的に取り組み溶接技術の普及に貢献した.

同氏の主な業績をあげると以下のとおりである.

（1）国内外の原子力発電所の改修工事において同氏らが自社開発した自動溶接 機を用いて現地作業員の溶接教育・訓練の指導を行い，溶接技術の向上と 普及に貢献した.

（2）原子炉の制御棒駆動機構ハウジング部取替え工法の開発では，2 力国 4 社 のプロジェクトの一員として特殊自動溶接機の開発を担当し，技術確立に 大きく寄与した。この成果は国内初の取替え工事にて実用化された.

（3）現職に移ってからは，広く社外からの溶接試験研究を受託し成果につなげ るとともに, 溶接技術の指導・育成にあたり, 技術・技能の普及に寄与し た.

以上のように，同氏が溶接技術の開発，普及および指導・育成に貢献した功績 は誠に顕著である。

関西支部

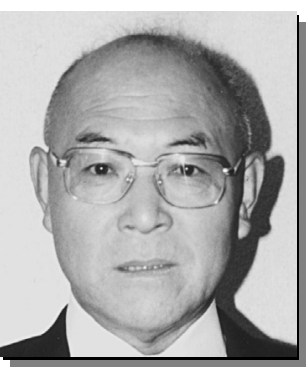

前田栄 一 氏 昭和7年10月16日生 前新明和工業(秼)
1. 溶接技能者の育成

(1) 技能五輪全国大会の電気溶接部門の競技委員ならびに兵庫県技能大会にお ける電気溶接部門の競技委員を長年勤め，溶接技能レベルの向上に尽力し た。

（2）産業界の溶接技能訓練責任者として 12 年間従事し，その間に社内外の溶接 技能者 32 名を技能五輪に出場させ， 6 つの県において県 1 位を 16 回，全国 大会10位内を 9 回輩出するなど溶接技能のレベル向上ならびに若手溶接技 能者の育成に尽力した.

（3）兵庫労働基準連合会のガス溶接およびアーク溶接特別教育講師を10数年勤 め, 中小企業に働く溶接技術者の育成に尽力している.

2. 溶接技術の開発とロボット化の推進

(1) 航空機，道路車両および産業プラント機器など幅広い製品分野において使 用される多種の材料に関する新しい溶接方法を開発するとともに，それを 現場に適用し，産業界の溶接技術の向上に貢献した.

（2）製造業の生産現場への溶接ロボットの導入に際し，ロボットの開発ならびに応用技術の開発に従事し, 成果の社外発表を通じて溶接作業のロボット化，省人化の普及に貢献した.

3. 過去に受けた主な賞 
（1）1970年11月，兵庫県職業能力開発協会より，永年競技検定委員を務めたことに対し表彰を受けた.

（2）1993 年 5 月，日本溶接協会より貢献賞を受けた.

（3）2006 年 5 月，西宮労働基準協会より，永年溶接安全教育に尽力したことに対し表彰を受けた.

東海支部

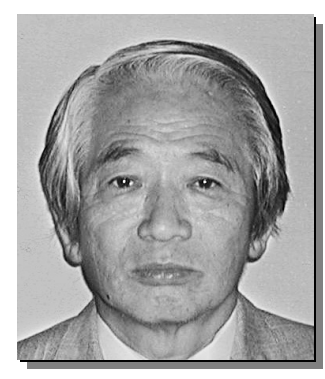

山下昇 一 氏 昭和15年8月 27 日生 大同工業大学創造性作セン 夕ー

山下昇一氏は，昭和35年以来46年間に渡って半自動アーク溶接を中心とした溶 接技術の実用化に携わり数々の業績を上げ，また学協会活動を通じ溶接技術の普 及にも尽力して来た. 主な業績は次の通り.

(1)主な研究開発

名古屋産業科学研究所勤務時には名古屋大学工学部に派遣され，炭関アーク溶 接の溶接施工上における溶接条件の確立に努め, 日本での炭酸ガスアーク溶接, とりわけ同半自動溶接の普及活動に多大な貢献をした.

大同工業大学では, 昭和 61 年より名古屋大学との共同研究により高張力鋼にお ける溶接部の水素遅れ破壊について当時では珍しい動的観察手法を確立し現象究 明に貢献した。

平成 3 年より, 鋳鉄の摩擦圧接法に関する研究に着手し, 鋳鉄の溶接に同溶接 法が最適であることを見出し，巣埋め溶接への実用化を成功させた。この技術は バルブの製作での異材接合へと発展した.

(2)溶接技術の教育および普及

大同工業大学においては，研究業務の支援ならびに学生の卒業研究活動推進に指導的な役割を果たし，教 員として後継者の育成に尽力した.

学外では昭和 45 年より，日本溶接協会中部地区溶接技能検定委員会委員，幹事を歴任し，溶接技能者の育 成に努めた。

また, 愛知県溶接技術競技会副審査委員長, 愛知労働基準協会ガス溶接技能講会講師およびアーク溶接等 特別教育講師として永年活躍し，地域における溶接技能伝承に貢献した.

(3)その他

昭和63年以来日本非破壊検査協会評議員および資格試験認証委員を務め，非破壊検査技術の非破壊検査技 術の普及に貢献した。

中国支部

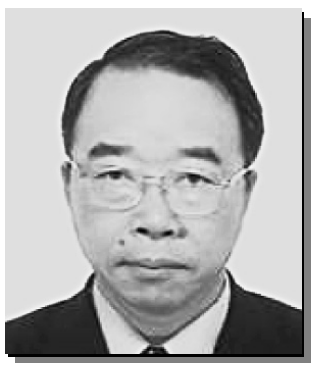

堀隆一氏 昭和 24 年9月11日生 神鋼 JFE 機器株式会社 専務取締役 堀＼cjkstart隆一氏は昭和50年京都大学大学院工学研究科治金学専攻修士課程修了，同 年 4 月(侏)神戸製鋼所加古川製鉄所に入社し製銑課に配属され，以来主として高炉 の操業，技術開発に深く関与した。その後，製銑技術担当課長，製銑課長，ジュ ッセルドルフ事務所課長，加古川製鉄所製銑部長，計画管理部長，高砂製作所長 を経て平成15年に神鋼機器(株)（現在は神鋼 JFE 機器(株)）専務取締役に就任した. この間, 1989 年にアメリカ鉄鋼協会最優秀論文賞, 1990 年に大河内記念技術賞を 受賞し，2001年から東南アジア鉄鋼協会日本代表委員として鉄鋼技術と溶接技術 をはじめとする鉄鋼周辺技術の国際普及に努めた。また，大阪大学大学院，京都 大学大学院の非常勤講師として教育にも貢献した.

現在，日本溶接容器工業会の技術委員長として，日本の高圧ガス溶接容器の製 造技術の発展と製品品質向上の中心的役割を担っている. その活動は, 高圧ガス 保安協会の移動容器規格委員, 高圧ガス容器規格委員のみならず, 高圧ガス容器 のISO 委員として国内・国際委員会に及んでいる.

平成16年から溶接学会中国支部商議員を務め，学協会の連携と溶接技術の普及 に注力している．溶接協会においては溶接技能検定員として活動すると共に，鳥取県溶接技能競技会委員長 として地域産業に密着した溶接技術・技能の向上に努めている.

以上のように，堀 隆一氏の永年にわたる溶接技術の発展・普及に貢献した功績は誠に顕著である. 


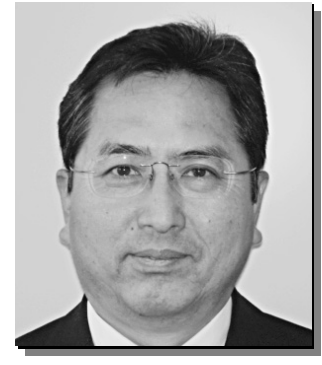

青 木 正 弘 氏 昭和26年12月4日生 広島菱重エンジニアリング (株)取締役製造部長
青木正弘氏は昭和 49 年 3 月大阪大学基礎工学部物性物理工学科を卒業，同年 4 月三菱重工業(株広島造船所（現在は三菱重工業(株広島製作所）に入社しボイラ工 作課に配属され，以来溶接技術担当として主に石油精製・石油化学・肥料など各 種プラント向けの高温高圧圧力容器や圧縮機の製造に従事した。平成 12 年 4 月溶 接組立課長，平成14年 6 月に同社広島製作所の機械工作部次長に，また平成18年 7 月に広島菱重エンジニアリング(侏)の取締役製造部長に就任し，その間，新技術 の導入，施工技術の開発など溶接生産技術の発展や溶接技術者・溶接技能者の育 成に尽力した。特に下記技術開発は溶接品質の向上，製品信頼性向上により国内 外のプラントの安全操業に大きく寄与した.

1）高温高圧圧力容器の溶接では，独自の多層巻容器（三菱コイレヤ）の溶接施 工技術の改良や製鋼・溶接材料メーカと協力して焼戻し脆化などの経年劣化 を防止する溶接施工技術を開発し国内外に多数の信頼性の高い圧力容器を供 給した。

2）圧縮機の製造では心臓部である高速回転する羽根車（インペラ）の製造に長 年にわたり関与し，年々高くなる圧縮機の性能向上要求に対応した狭隘部の 高能率高品質溶接技術の開発，改良に貢献した。

また平成 4 年から日本溶接協会中国地区溶接検定委員会検定委員を，平成12年から溶接学会中国支部商議 員を努め，中国地方の溶接技術の向上及び普及に貢献した.

以上のように，青木正弘氏の長年にわたる溶接技術の発展・普及に貢献した功績はまことに顕著である.

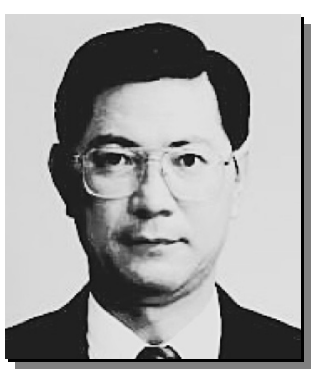

有 村 幸 二 氏 昭和 26 年 4 月 16 日生 宇部興産侏建設資材カンパ ニー生産・技術本部設備管 理部設備管理部長
有村幸二氏は昭和50年 3 月大阪大学工学部溶接工学科卒業，同年 4 月宇部興産 (株機械事業部（現在宇部興産機械侏平成 12 年分社）に入社。製造部に配属され， 以来主として産業機械の設計，製作，製造技術開発に深く関与した。平成 11 年 4 月に同社産機製造部長，平成 14 年 6 月 TMS 事業推進部長に就任し，その間化工機, 運搬機，橋梁·鉄構業界における溶接技術の進歩発展に寄与した。特に下記技術開 発および取り縓め業務は内外より大きく脚光を浴び，高い評価を得ている.

1）化工機では，低合金鋼（Cr-Mo，3.5～9 Ni）や各種クラッド鋼製の圧力容器, 熱交換器の溶接施工法確立に寄与したが，特に純 $\mathrm{Ni}$ を使用した苛性ソーダ 濃縮，固化設備の溶接技術開発は斬新なアイデアで従来の常識を覆し，純 $\mathrm{Ni}$ 溶接材料の使用を可能にし設備の腐食損傷改善に大きく寄与した.

2）運搬機では，エアー浮上コンベアの製造技術開発に寄与したが，特に東京電 力常陸那珂石炭火力発電所殿向けの長大コンベアの連続自動双子管製造ライ ンの技術開発では溶接精度確保と量産，設備コスト削減に努めた。

3）橋梁では溶接のライン化，自動化に寄与したが，特に少主桁化に伴う極厚フ ランジの狭開先全自動上向き溶接技術開発に寄与した。

また，平成 4 年より現在まで日本溶接協会中国地区溶接技術検定委員，平成10年より平成 17 年度まで溶接 学会中国支部商議員, 幹事を務め, 中国地区の溶接技術の向上および普及に貢献すると共に学協会の連携に 注力している.

現在平成16年 4 月より宇部興産侏に復職し, 建設資材カンパニーの設備管理部長として設備工事, メンテ ナンスの面で溶接技術の応用普及に寄与している.

以上のように，有村幸二氏の長年にわたる溶接技術の発展・普及に貢献した功績は誠に顕著である. 


\section{○州支部}

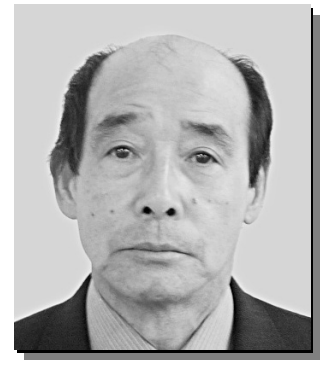

川 崎幸 雄 氏 昭和 23 年 2 月 9 日生 三菱重工業侏長崎造船所役 職主任

川崎幸雄氏は昭和 45 年 4 月三菱重工業(株)長崎造船所に入社，第二工作部製午第 一課に製缶溶接職として配属され，その後一貫して溶接業務を担当してきた。平 成14年 3 月までは，火力発電プラントの配管及びボイラ管寄せの工場製造におけ る溶接作業に従事するとともに，その知識と経験を生かして国内外の火力発電プ ラント建設現地においても溶接作業及び溶接指導員業務に従事した。この間，同 社の高合金鋼及びステンレス鋼溶接の礎を築くとともに，各種自動溶接設備の開 発，若手溶接士の育成などを通じて溶接技術の発展に大いに貢献してきた．平成 12年にはその技能が認められて職業能力開発協会から高度熟練技能者の認承を受 けている.さらに, 平成14年 4 月からは同部生産技術課生産技術一係教育センタ 一の教育担当主任として社内溶接士の指導・育成及び技量管理, 社内技術研修所 での溶接技術の指導に加え，関連協力会社溶接士の指導，技術系高等学校への溶 接技術啓蒙活動にも従事するとともに，日本溶接協会長崎支部の理事も務め現在 に至っている. 尚, 同氏が教育担当主任となって指導した溶接士は日本溶接協会 主催の技量コンクールにおいて，毎年長崎県大会で優勝している．以上のように， 同氏は社内外溶接士の指導・育成を通じて溶接業界に大いに貢献していることは本溶接技術普及賞受賞に十 分に值すると考えここに推薦する. 
溶接学会研究発表賞は, 平成6年に創設され, 全国大会研究発表において, 発表内容及び発表の仕方の両者 が優れた35才以下の研究発表者に対し，会長から贈られます.

\section{春季全国大会}

1. 発表題目：Sn-Ag 系はんだ $/ \mathrm{Cu}$ 接合強度に及ぼす界面微細組織の影響 発表者： 大阪大学 接合科学研究所 西川宏 君

2. 発表題目: TWIP 鋼の摩擦㩭拌接合
発表者:
香川大学工学部 上 路 林太郎 君

3. 発表題目：マグ溶接に扔ける最適シールド条件の検討
発表者:
(侏)安藤鉄工建設 金 谷 貴 志 君

4. 発表題目：高板厚比三枚重ね抵抗スポット溶接プロセスの開発

(第 1 報）一薄板/厚板間に抒けるナゲット形成現象の検討一

(第 2 報）一加圧力・溶接電流制御を利用した溶接プロセスの検討一

発表 者:

JFE スチール(株) 沖田 泰明 君

\section{秋季全国大会}

1. 発表題目：溶接金属におけるアシキュラーフェライト生成サイトのその場観察
発表 者:
大阪大学接合科学研究所 寺 崎秀 紀 君

2. 発表題目：摩擦攪挥プロセスによるC60分散AZ31の創製
発表 者:
大阪市立工業研究所 森 貞 好 昭 君

3. 発表題目：アシストガスフリーレーザ切断の限界切断速度に及ぼす焦点外しの影響
発表 者:
三重大学大学院 水 越 健一君

4. 発表題目：純チタンの突合せレーザ溶接時の隙間モニタリングと適応制御 発 表 者：大阪大学接合科学研究所 八 洋介君

5. 発表題目：フェムト秒レーザー駆動衝撃波によるチタン高圧相凍結 発表者： 大阪大学大学院 佐 野 智一 君

6. 発表題目：亜鉛めっき鋼板のレーザブレージングにおけるピット発生機構の解明

発 表 者: 大阪大学接合科学研究所 木 村 静 太君

7. 発表題目：BGAはんだ接合部の温度サイクル負荷におけるチップ発熱の影響
発表者:
大阪大学大学院 江 草
稔 君 
溶接学会シンポジウム賞は, 平成 7 年度に創設され, 溶接学会の研究委員会が企画・運営し, 溶接学会が主 催し規定に定められた一定の基準を充たすシンポジウムにおいて発表される論文の中で，学問上・技術上優 秀と認められる論文の著者に対し, 会長から贈られます。

\section{溶接構造シンポジウム2006}

\section{優秀論文賞}

「機械的性質の温度依存性を考慮した相変態応力解析方法」

寺崎俊夫君，川上博已君，長谷川弘毅君（九州工業大学），福谷理明君（日本鋳鍛鋼（株)）

$\lceil 3$ 電極 $\mathrm{MAG}$ 高速水平すみ肉溶接施工法の開発」

中野利彦君，長岡茂雄君，森本朋和君，有田 大君（(株）神戸製鋼所）

「画像処理技術による溶接構造物の残留応力・溶接変形の逆問題解析手法」

中村春夫君（東京工業大学）

\section{Mate 2007}

\section{Mate 2007 優秀論文賞}

「電解 $\mathrm{Ni} / \mathrm{Au}$ めっき BGA 鉛フリーはんだ接合部の衝撃強度劣化メカニズムと高強度化 山本健一君（株ルネサステクノロジ），赤星晴夫君，加藤隆彦，川村利則君（株）日立製作所） 木本良輔君（侏ルネサステクノロジ），佐藤了平君（大阪大学）

\section{Mate 2007 研究奨励賞}

$\lceil\mathrm{Sn}-3.0 \mathrm{Ag}-0.5 \mathrm{Cu}$ 鉛フリーはんだにおける腐食メカニズムの解析」 
溶接学会奨学賞は平成 9 年 12 月に創設され，溶接・接合分野へのより強い関心を促し，次世代の溶接・接 合研究者，技術者としての発展を期待し，人格・学業とも優れた学生に贈られます.

各支部の推薦に基づき，平成18年度溶接学会奨学賞を受賞されました方々は次のとおりです。

\section{北海道支部}

「曲線 2 主桁橋における溶接部の応力集中と耐疲労性」

小畑 潤平君 北海道大学大学院工学研究科修士課程環境創生工学専攻 2 学年

\section{東北支部}

「超硬合金と鋼の高温ろう付けにおける最適条件の決定」

\section{東部支部}

竹澤 大輔君 岩手大学大学院工学研究科材料物性工学専攻博士前期課程 2 年生

「狭開先溶接における数值シミュレーション」

高橋 祐介君 埼玉大学大学院理工学研究科博士前期課程環境制御工学専攻 2 年

$\lceil\mathrm{Fe}-\mathrm{C}-\mathrm{Mn}-\mathrm{Si}$ 系微細粒高強度鋼の電子ビーム溶接 HAZ 組織の解析」

松岡 範幸君 芝浦工業大学大学院工学研究科材料工学専攻修士課程 1 年

「柱梁溶接接合部における溶接金属の強度の推定と溶接条件の管理手法に関する研究」

田中 祐以君 信州大学大学院工学系研究科社会開発工学専攻

\section{東海支部}

「高張力鋼のレーザーアークハイブリッド溶接の研究」

劉 忠杰君 名古屋大学大学院工学研究科博士 3 年

$\lceil\mathrm{Al} / \mathrm{Cu}$ 大気中拡散液化接合に及ぼす初期表面粗さの影響」

中嶋 純也君 三重大学大学院工学研究科前期課程 2 年

\section{関西支部}

「延性き裂進展を支配する鋼材の力学的特性に関する基礎検討」

岡村 有貴君 大阪大学応用理工学科マテリアル生産科学科目生産科学コース

「耐熱合金へのステライト合金のマイクロスパークコーティング」

鷿見 信行 大阪大学大学院工学研究科マテリアル生産科学専攻博士前期課程 2 年

「銀ナノ粒子を用いた接合法の開発」

巽 裕章君 大阪大学大学院工学研究科生産プロセス講座機能化プロセス工学領域

「フェムト秒レーザー照射による非平衡材料創製」

高橋＼cjkstart謙悟君大阪大学生産プロセ又講座機能化プロセス工学領域

\section{中国支部}

「異材レーザ溶接部の凝固割れ感受性評価法に関する研究」

河崎 篤志君 広島大学大学院工学研究科機械システム工学専攻博士課程前期 2 年

\section{九州支部}

「スポット溶接によるアルミニウム合金の異材接合部の強度に及ぼす反応層の影響」

邱然鋒君 熊本大学大学院自然科学研究科産業創造工学専攻博士後期課程 1 年

「面内ひずみを用いたねじれ曲面成形方法の検討」

藤井 美保君 九州工業大学大学院工学研究科物質工学専攻マテリアル創成加工学分野修士 2 


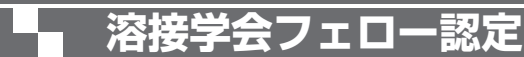

溶接学会フェローは，平成15年10月 8 日に創設され，溶接・接合に関する工学・技術と社会および本会の 発展に顕著な貢献をなされた方に溶接学会フェローの称号を抒贈りし，会員の地位向上・国際活動をより円 滑にし，あわせて本会の一層の活性化をはかることを目的としております。

各支部長，各種研究委員会委員長及び理事からの推薦に基づいて審査し，第75回通常総会において認定証 を贈呈しました。

（入会年月順）

篠田 剛君 沓名 宗春君 寺崎 俊夫君 西本 和俊君 中山 繁君 日置 進君

渡辺健彦君中西保正君塚本進君 大北茂君安田功一君前川仁君

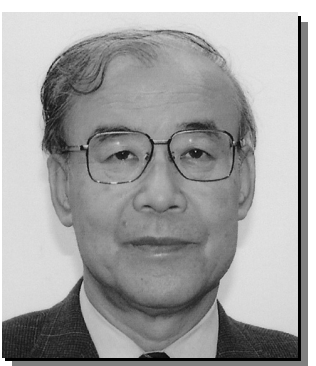

莜田剛君

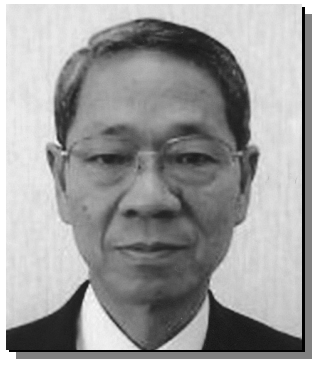

中 山

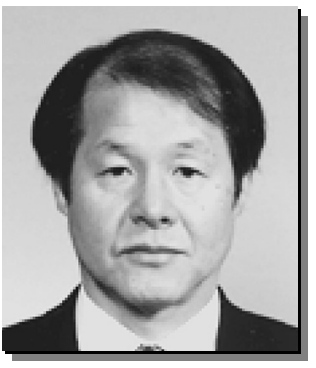

塚 本

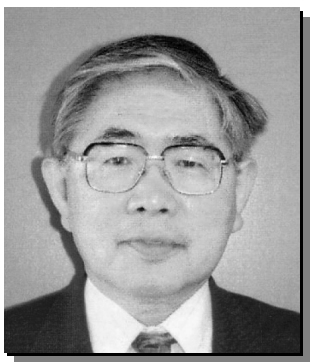

沓名宗春 君

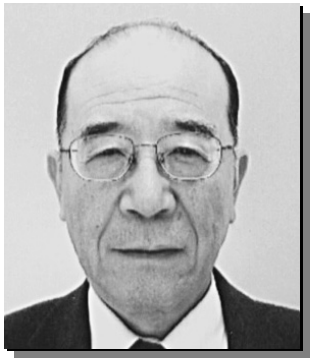

日置進君

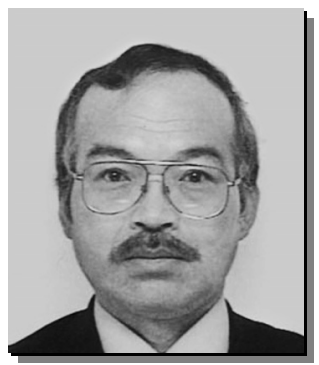

大北茂君

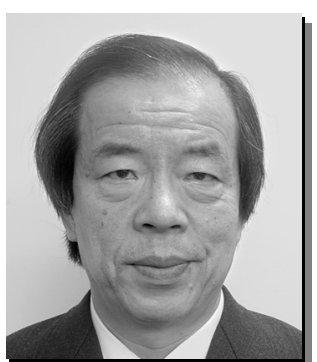

寺 崎 俊 夫 君

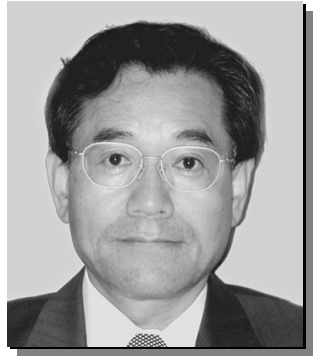

渡辺健彦君

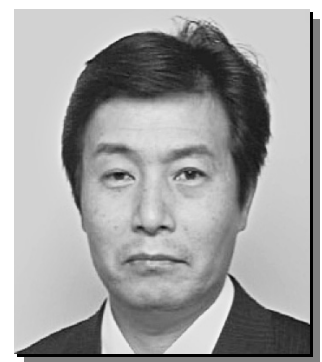

安 田 功 - 君

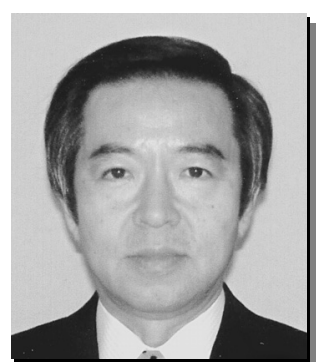

西 本 和 俊 君

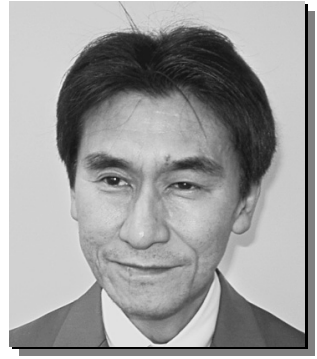

中 西 保 正 君

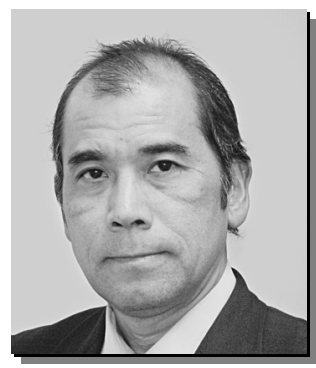

前川仁 君 
STWJ 誌との提携により，本会よりSTWJ 誌へ推萀された論文は次のとおりです.

1.「Hollow Cathode Arc 溶接現象のモデル化」

宮坂史和 迎井直樹 正箱信一郎 黄地尚義 (大阪大学工学研究科知能 - 機能創 成工学専攻)

櫻井智子 (大阪大学工学研究科知能 - 機能創成工学専攻 (現: (陎)日本総合研究所 $)$ )

(論文集 24 巻 3 号)

2. 「深溶込みレーザ溶接に扔けるポロシティの発生機構

一大出力 $\mathrm{CO}_{2}$ レーザ溶接に扔けるポロシテイ抑制に関する研究（第 2 報）一」

川口 勲 (物質・材料研究機構 (現：石川島播磨重工業(㭌))

塚本 進 荒金吾郎 (物質・材料研究機構)

中田一博（大阪大学接合科学研究所）

(論文集 24 卷 4 号)

3.「低变態温度溶接材料を用いた高張力鋼溶接継手の大気腐食挙動」

銭谷 哲 (物質・材料研究機構 (現：三菱重工業(侏))

西村俊弥 平岡和雄 (物質・材料研究機構)

早川直哉（物質・材料研究機構（現：JFE スチール(侏)）

(論文集 24 巻 4 号)

4.「「イッチバック溶接のバッキングレ ス V開先円周溶接への適用」

山根 敏 田中涁人 金子裕良 大嶋健司 (埼玉大学)

山本 光 $($ 日立建機株)

(論文集 25 巻 1 号)

5. 「超深溶込み TIG 溶接における溶融池形状に及ぼす $\mathrm{He}-\mathrm{O}_{2}$ シールドガス中の $\mathrm{O}_{2}$ 量の影響」

陸 善平 (大阪大学接合科学研究所, 中国科学院金属研究所)

藤井英俊 野城 清 (大阪大学接合科学研究所)

佐藤豊幸（大陽日酸株）

(論文集 25 巻 1 号)

6.「時分割 $\mathrm{X}$ 線回折システムによる純チタン溶接金属凝固・固相変態の特性評価」

寺崎秀紀 小溝裕一 (大阪大学 接合科学研究所)

西野文裕＼cjkstart池田勝彦（関西大学工学部）

(論文集 25 巻 1 号)

7.「放射光を利用したオーステナイト系ステンレス鋼溶接凝固過程の解析

一オーステナイト系ステンレス鋼溶接金属凝固組織の解析一」

小薄孝裕 米村光治 小川和博 (住友金属工業(侏)

小溝裕一 寺崎秀紀（大阪大学接合科学研究所）

(論文集 25 巻 1 号)

8. 「速度依存性を考慮したオーステナイト系ステンレス鋼溶接凝固過程の数值解析

一オーステナイト系ステンレス鋼溶接金属凝固組織の解析一」

小薄孝裕＼cjkstart平田弘征小川和博（住友金属工業(掣)

(論文集 25 巻 1 号)

9.「 「開先片面裏当てなしスイッチバック溶接におけるトーチ摇動方法抒よび裏ビードのフィードフォワー ド制御」

山根 敏 石川智也 金子裕良 大嶋健司 (埼玉大学)

中嶋 徹 山本 光 (日立建機株)

(論文集 25 巻 1 号)

10.「フェライト系高温用鋼溶接熱影響部のクリープ強度と組織変化に及ぼす $\mathrm{C}$ 量の影響

一フェライト系高温用鋼の HAZ 軟化抑制一」

平田弘征 小川和博（住友金属工業(株)

(論文集 25 巻 2 号) 